\title{
CAN CONSUMERS DETECT LEMONS? INFORMATION ASYMMETRY IN THE MARKET FOR CHILD CARE
}

\author{
H. Naci Mocan \\ Working Paper 8291 \\ http://www.nber.org/papers/w8291 \\ NATIONAL BUREAU OF ECONOMIC RESEARCH \\ 1050 Massachusetts Avenue \\ Cambridge, MA 02138 \\ May 2001
}

This research is supported by a grant from the Smith Richardson Foundation to the NBER (Grant No. 9901 651), and an NBER Nonprofit Sector Research Grant. Paul Niemann, Kaj Gittings, and Damba Lkhagvasuren provided outstanding research assistance. I thank Jeffrey Zax, Patrick Emerson, Madeline Mocan and Murat Iyigun, and participants of the 2001 SOLE Conference in Austin, Texas for helpful comments. The views expressed herein are those of the author and not necessarily those of the National Bureau of Economic Research.

(C) 2001 by H. Naci Mocan. All rights reserved. Short sections of text, not to exceed two paragraphs, may be quoted without explicit permission provided that full credit, including $($ notice, is given to the source. 
Can Consumers Detect Lemons?

Information Asymmetry in the Market for Child Care

H. Naci Mocan

NBER Working Paper No. 8291

May 2001

JEL No. D8, J1, L1, L2, L3, L8

\title{
$\underline{\text { ABSTRACT }}$
}

This paper applies direct tests for adverse selection and moral hazard in the market for child care. A unique data set containing quality measures of various characteristics of child care provided by 746 rooms in 400 centers, as well as the evaluation of the same attributes by 3,490 affiliated consumers (parents) is employed. Comparisons of consumer evaluations of quality to actual quality show that, after adjusting for scale effects, parents are weakly rational. The hypothesis of strong rationality is rejected, indicating that parents do not utilize all available information in forming their assessment of quality. Parent characteristics impact the accuracy of their evaluations. An analysis of easy-to-observe versus difficult-to-observe aspects of quality reveals that parents are trying to extract signals more heavily in cases of difficult-to-observe items. A comparison of parent assessments to results obtained from standard quality production functions reveals that, for the most part, parents interpret the signals incorrectly.

The results demonstrate the existence of information asymmetry and adverse selection in the market. There is some limited evidence for moral hazard as nonprofit centers with very clean reception areas tend to produce lower level of quality for unobservable items. These results provide an explanation for low average quality in the child care market.

\author{
H. Naci Mocan \\ Department of Economics \\ University of Colorado at Denver \\ Campus Box 181, P.O. Box 173364 \\ Denver, CO 80217-3364 \\ and NBER \\ Tel: (303) 556-8540 \\ Email: nmocan@carbon.cudenver.edu
}




\section{Can Consumers Detect Lemons? \\ Information Asymmetry in the Market for Child Care}

\section{Introduction}

In his seminal paper, Akerlof (1970) shows that in a market with asymmetric information between buyers and sellers, adverse selection is likely to result. If it is difficult for buyers to assess the quality of the product, and if quality is costly to produce, sellers of high quality products will not be able to command higher prices for higher quality. As a result, high quality products will withdraw from the market, leaving the "lemons" behind. Although Akerlof's paper is followed by a number of theoretical articles that extended the idea (e.g. Leland 1979, Heinkel 1981, Wolinsky 1983, von Ungern-Sternberg and von Weizsacker 1985, Shapiro 1986), only a handful of papers tested the presence of this type of market failure. Bond (1982) and Genesove (1993) analyzed the market for used cars, Greenwald and Glasspiegel (1983) investigated the New Orleans slave market, Chezum and Wimmer (1997) and Rosenman and Wilson (1991) examined the market for thoroughbred yearlings, and the market for cherries, respectively. Paucity of data prevented these papers from employing direct measures of product quality. ${ }^{1}$ Consequently, researchers used indirect methods to test the presence of lemons markets. The main empirical procedure to test for information asymmetry-based adverse selection has been to investigate the link between the price of the good in question and observable characteristics of the good which may provide a quality signal to the buyer. For example, Genesove (1993) suggested that new car dealers differed from used car dealers in the propensity to sell trade-ins on the wholesale market. Used car dealers are expected to keep high quality used cars and take low quality ones to block auctions. Thus, if buyers can distinguish between different dealer types, they should pay a price premium for those used cars sold by new car dealers. Similarly, Chezum and Wimmer (1997) investigated the relationship between a yearling's auction price and observable seller characteristics; and Rosenman and Wilson (1991) analyzed the link between wholesale cherry prices and seller characteristics that may signal quality.

\footnotetext{
${ }^{1}$ Bond (1982) investigated whether there was a difference between the maintenance records of pickup trucks that were purchased used and those that were original-owner trucks. To the extent that maintenance records are proxies of quality, this paper is an exception.
} 
The average quality of center-based child care provided in the U.S. is thought to be mediocre, especially compared to the quality of care provided in other developed countries (Whitebook, Howes and Phillips, 1990; Mocan, 1997; Bergman, 1996). There is considerable interest among policy makers to find ways to increase the quality of child care. One main argument in favor of policies targeted to increase child care quality is that child care has aspects of a "public good" or "merit good." This means that high quality child care not only benefits its private consumers, but also the society as a whole through positive externalities. For example, if high quality care increases the cognitive skills of children and their labor market opportunities as young adults, high quality child care today would benefit society tomorrow by helping create more educated and productive individuals with more earning power, who are also less welfare dependent and less crime-prone. ${ }^{2}$

This paper focuses on the market for child care, where the model of information asymmetry between the producer and the consumer described above is particularly applicable. It is plausible to hypothesize that the provider (child care center) is informed about the level of quality of its service, but the consumers (parents) have difficulty in distinguishing between the quality levels of alternative centers. The reason for parents' lack of information on center quality may be their inability to spend significant amounts of time at the center to observe various dimensions of the operation. Mocan $(1995,1997)$ shows that it costs $\$ 243$ to $\$ 324$ per child per year (in 1993 dollars) to increase the quality of child care services from "mediocre" to "good." Given that it costs more to produce higher quality, providers would not have an incentive to increase the quality of their services if they cannot charge higher fees. If parents cannot distinguish between high-quality and low-quality centers, they would not be prepared to pay higher fees. Under this scenario, high quality centers exit the market, average quality falls, and eventually the market is filled primarily with "lemons" that provide mediocre quality.

This paper improves upon earlier empirical studies on information asymmetry and adverse selection in a number of ways. First, a direct measure of product quality is used. As described in Section II, the paper employs a unique data set which contains well-developed measures

2 See Poterba (1996) for a detailed discussion of the reasons for government intervention in health care and education markets. 
of the quality of child care services. This allows for a direct comparison of the quality of services produced by the provider with the quality assessment of consumers (parents) to test hypotheses about consumers' weak and strong rationality. Second, the paper investigates whether consumers' characteristics impact the accuracy of their assessments of quality. Third, firm-specific determinants of consumers' errors in quality assessment are analyzed. This allows us to investigate whether provider characteristics are taken as signals of quality by consumers, which is the primary vehicle to test for adverse selection. Fourth, the detail of the data set enables us to entertain a number of important questions. For example, we can identify easy-to-observe and difficult-to-observe aspects of the services. An example of the former is the cleanliness of the reception area of the child care center, and an example of the latter is the quality of teacher-child interaction. This information enables us to investigate the extent to which consumers have difficulty in extracting information due to "unobservability." Similarly, we test whether race-matching between parents and the classroom teacher creates a "misplaced trust" for the parents that would inflate their quality ratings, and whether the avenues through which consumers gather information have an impact on the accuracy of their quality assessments. Fifth, estimation of quality production functions enables an analysis as to whether consumer perceptions are consistent with reality, as well as an investigation of moral hazard.

The investigation of these issues is significant, not only because they provide insights into information asymmetry-based market failure in this particular market, but they can also be helpful for understanding similar markets. Section II describes the data and the measure of quality. Section III presents the descriptive statistics of the data. Sections IV and V investigate consumers' weak and strong rationality, respectively. Section VI analyzes the determinants of prediction errors, and Section VII is the conclusion.

\section{Data and the Measurement of Quality}

As described by Hayes, Palmer and Zaslow (1990), Lamb (1998) and Love, Schochet, and Meckstroth (1996), there are two distinct concepts of quality in child care. The first one is referred to as "structural quality," which describes the child care environment as measured by such variables as the child-staff ratio, group size, and the average education of the staff. These structural 
measures of quality are thought of as inputs to the production of "process quality," which measures, among other things, the nature of the interactions between the care provider and the child, and activities to which the child is exposed. This paper employs widely-used measures of process quality designed by psychologists, as well as various structural measures of quality as explained below.

The data were compiled with the collaboration of economists, psychologists and child development experts from the University of Colorado at Denver, Yale University, University of North Carolina at Chapel Hill and UCLA during the first half of 1993 on a stratified random sample of approximately 100 programs in each participating state, evenly split between for-profit and nonprofit centers. The data set includes information on child care centers located in metropolitan regions in four states: Los Angeles County in California, the Front Range of Colorado, the New Haven-Hartford corridor in Connecticut, and the Piedmont Triad in North Carolina. These regions were selected for their regional, demographic, and child care program diversity. The data set includes only state-licensed child care centers serving infant-toddlers and/or preschoolers that offered services at least six hours per day, 30 hours per week, and 11 months per year. To be used in the sample, a center had to have been in operation at least one full fiscal year, and the majority of children had to attend at least 30 hours and five days per week. ${ }^{3}$

Data collectors obtained in-depth information on centers through on-site interviews with center administrators and owners, and reviews of center payroll and other records. Also, two observers visited each center for one day to gather data on classroom and center structural and process quality. As a result, the extraordinary detail of the data allows one to measure classroom quality and other variables with more precision than was possible before.

At each center two classrooms were randomly chosen, one preschool and one infanttoddler. Infant-toddler rooms were defined as those where the majority of children were less than two-and-a-half years old. Preschool classrooms were defined as those where the majority of

3 Most of the data collectors were individuals who were involved in early childhood education, such as former child care teachers, assistant teachers, or center directors. After a week-long training program, data collectors were required to carry out actual observations and data collection in actual centers. During these practices inter-rater reliability was evaluated, and site coordinators, who were individuals with experience in administering the survey instruments, provided additional training if the agreement between observers was less than 80 percent. It should be noted that this is the standard procedure to train data collectors in child development research, and this study arguably provided some of the best training to the data collectors in terms of the duration of the training, emphasis on inter-rater reliability and providing in-person training (as opposed to training through videos, etc.) 
children were at least two-and-a-half years old but not yet in kindergarten. If a center did not serve infant-toddlers, two preschool rooms were observed. Data were collected in a total of 228 infanttoddler rooms and 518 preschool rooms.

Trained observers used two instruments to comprehensively assess the process quality of care provided by children: The Early Childhood Environment rating Scale (ECERS) (Harms and Clifford 1980), and its infant-toddler version, the Infant-Toddler Environment Rating Scale (ITERS) (Harms, Cryer and Clifford 1990). The instruments contain questions that measure the quality of personal care routines, furnishings and display for children, language-reasoning experience, fine and gross motor activities, creative activities, social development and adult needs. Each question is scored on a seven-point scale from inadequate to excellent. These are objective measures and do not involve other, possibly intangible aspects of quality parents may value, such as religious affiliation or proximity to home or work. Specific questions included in ECERS and ITERS measure conditions such as the structure of the arrival and leaving times, meals and snacks, nap and rest time, room decoration, keeping children neat and clean, equipment for active play, and block play. The same questions are given to the parents and their evaluations of each of these items are recorded. 4

Observers' ratings of the individual questions in ECERS and ITERS are averaged to obtain the room-level measure of process quality for preschool, and infant-toddler rooms, respectively. These are standard aggregate measures of process quality for infant-toddler and preschool rooms, which are argued by developmental psychologists to impact child outcomes such as cognitive development (Hayes et al., 1990). Averaging the answers to the same questions provide information on parents' overall rating. Some questions in ECERS and ITERS pertain to aspects of care that are more difficult for parents to observe. For example, it is easy for a parent to assess whether the center staff provided friendly greetings for all parents and children during arrival and departure, whether the departure was organized, and whether parents and teachers shared information during arrival and departure. On the other hand, it may be difficult for a parent to determine the quality of

\footnotetext{
4 There were no statistically significant differences between centers that participated in the study and centers that declined to participate with respect to such characteristics as the legal capacity of the center, age of the center, auspice type, enrollment and the age group of children served. Similarly, no systematic state and auspice differences are found in the return rates for parent surveys. Details can be found in Mocan (1997) and Cryer and Burchinal (1997).
} 
the interaction between the child and the teacher in the classroom. Parents' ability to accurately assess the quality of a given aspect of the child care services may depend upon whether they can easily observe that particular aspect. For this reason, two other measures of quality are created: one that pertains to easy-to-observe aspects of center operation, and another which pertains to difficultto-observe aspects. The classification of the questions in ECERS and ITERS into easy-to-observe and difficult-to-observe is done in the following way. Parent surveys allow the parents to indicate if they "don't know" enough about that particular question to provide a rating. In those instances, instead of rating the question from 1 to 7 , the parent chooses the option of "don't know" on the survey. If a particular question received at least $10 \%$ of "don't know" answers from all parents, that question is classified as unobservable. Using this algorithm, easy- and difficult-to-observe items are identified and their individual ratings are averaged. The results were insensitive to the cutoff value. In addition, a subjective classification of the questions generated very similar results (Mocan 2000). Finally, analyses are performed using individual questions in ECERS and ITERS instruments.

It can be argued that parents may find certain center characteristics more valuable than quality. For example, even if a particular classroom in a given center receives a low quality rating by child development specialists, if that center is close to a parent's place of work, the classroom may be of high quality to the parent because the parent could visit the center easily during the day, or can get to the child quickly in case of an emergency. Similarly, if parents care only about a "bare-bones" child care service and a "warm body as a teacher" whose main task is to keep the children safe in the classroom, then information asymmetry might not be a major factor for market failure, because under this scenario parents do not care about information on quality in the first place. Another way to put this issue is to state that the quality of the services provided for children has dimensions that include parents' preferences concerning the child care arrangements, such as the travel distance between home and the center, and whether the provider shares the same religion and values of the parents. This suggests that a particular parent's perception of the quality of a given classroom may diverge from the child care experts' evaluation.

The surveys given out to the parents include questions on how important parents think particular aspects of ECERS and ITERS are for their children. Parents can choose three alternatives: 1, 2 and 3; 1 indicating "not important," and 3 indicating "very important." An 
overwhelming majority of the parents chose "very important" for most of the questions. For example for all the questions in ECERS, at least 60 percent of parents of preschool children indicated that those questions were very important for their children, with the following exceptions: Only 53 percent of the preschool parents indicated that block play was very important for their children; 37 percent indicated sand and water play were very important; and 59 percent thought space for child to be alone was very important. For infant-toddler parents, the particular items of the ITERS which were of the lowest importance for the parents were: Sand and water play, where 54 percent of the parents indicated that this was very important; and activities for different cultures where 58 percent of the parents said this was very important for their children. Thus, parents strongly care about the various dimensions of the classroom operation as measured by ITERS and ECERS. Furthermore, there is no reason to believe that parents' rating of very specific aspects of the classrooms would be contaminated by the other dimensions parents may find valuable, such as travel distance. For example, there is no reason to think that parents would believe that the quality of meals/snacks is mediocre, but they would nevertheless inflate their rating on meal/snack quality because the center is close to their home.

It is reasonable to argue that if the quality of care measured this way has no impact of child outcomes then there is little reason to worry about provision of low quality care and the problem of information asymmetry. The literature on child development has not provided conclusive evidence on the impact of quality of care on child development, primarily because of the methods employed. ${ }^{5}$ However, regardless of the strength of the relationship between quality of child care and child outcomes, information asymmetry is an issue because, as discussed above, parents believe that quality measured this way is important to them. Thus, parents' willingness to buy a given good (e.g. well supervised nap time) would be curtailed if they could not determine accurately the level of quality of the good. Put differently, if there was no relationship between quality of care and child outcomes, the problem of information asymmetry becomes analogous to that found in other markets, such as used cars. Similar to a consumer who thinks that a good car engine is important for her, the evidence presented above shows that parents think an overwhelming majority of the items listed in the questionnaire are important for them. Thus, similar to the market for used cars, if parents cannot determine the level of quality of these items, adverse selection in the market will result, and average

5 A discussion of empirical problems of literature is provided by Mocan (2000), Blau (1997). 
quality of care will go down. Even if there was no impact of quality on child outcomes this is a market failure. If, in addition, quality of care has a positive impact on child outcome, then the problem has a "public good" dimension in addition to its "private consumption" dimension because, in this case high quality child care creates positive externalities for society.

Data on socio-economic and labor market characteristics of 1,035 teachers and assistant teachers from these 400 centers as well as data on 3,134 parents whose children attended the centers were collected. These data are used to create classroom-specific variables such as average teacher experience, group size and staff-child ratios as well as parent information. The details of the data are presented in the next section.

\section{$\underline{\text { III. Descriptive Statistics of the data }}$}

The descriptive statistics of parents' assessment of individual items in ITERS and ECERS surveys, and the corresponding actual rating (assigned by trained observers) are displayed in the Appendix in Table App-1. To conserve space the table reports the 19 questions that are identically worded between ECERS and ITERS surveys. Other questions revealed very similar patterns (Mocan 2000). The way the questions are phrased in the surveys given to parents is displayed under “description." Because of space limitations, parent surveys included shortened descriptions of individual questions in comparison to the ones seen by trained observers. Potential implications of this are discussed below. Immediately evident in Tables App-1 is the fact that parents over-estimate the quality of their children's classrooms as compared to the rating given by trained observers. This behavior was reported in previous research (Cryer and Burchinal 1997).

Table 1 presents the characteristics of the parents. Average parent age is 33. Fathers represent seven percent of the parents who responded to the survey. Seventy-eight percent of the families do not receive any subsidy, 72 percent of the parents are married. Seventy-three percent of the parents are white. The Same Race variable indicates the matching of race between the parent and classroom teacher. This variable takes the value of one if the parent and teacher(s) in the classroom are of the same race, and zero otherwise. It will enable us to test the hypothesis of whether race-matching between the parent and the teacher has an impact on parent's quality assessment. 
Seventy-four percent of mothers work either part-time or full-time. Note that this variable pertains to the mother of the child, even when the parent who responded to the survey is the father. Fifty-six percent of the children whose parents responded to the survey receive more than 31 hours of care per week. The last six variables in Table 1 pertain to the way in which parents gather information about their child's classroom. In the survey given to parents they were asked how they "find out what happens in their child's care." The alternatives were: talking to the teacher, talking to the director, talking to other parents, watch the classroom at drop-off and pick-up times, drop in on the classroom unexpectedly, and from what the child says or does. These variables are not mutually exclusive.

Table 2 presents classroom characteristics. These are the classrooms affiliated with respective parents. Average teacher age is 35. If there is one teacher in the classroom, this variable is the age of that teacher. If there is more than one teacher, it is the average age of the teachers in the room. Note that the age, experience and race information presented in Table 2 pertains to teachers only, and does not include assistant teachers. Each classroom is observed throughout the day by data collectors, and the group size and the child-staff ratio are recorded five different times. The variable Group Size is the average value of the recorded group size of the classroom, and Staffchild ratio is the average staff-child ratio of the classroom. Because there are significant differences in both Group Size and Staff-child ratio by the age group of children, the descriptive statistics of these variables are reported by classroom type. Classroom size for preschool children are larger than those of infant/toddlers; similarly the staff-child ratio is lower in the former.

Table 3 presents the characteristics of the centers. For-profit takes the value of 1 if the center is for-profit, and 0 if it is nonprofit. National Chain is also a dichotomous variable, indicating whether the center is part of a for-profit national chain. On-Site is set to 1 if the center is a worksite child care center, and zero otherwise. Publicly Regulated is 1 if the center receives public money, either from the state or federal government, tied to higher standards (above and beyond normal licensing regulations), and 0 otherwise. This group includes Head Start programs, centers where 20 percent or more of their enrollment constitute special needs children, special preschool programs sponsored by the State or Federal Department of Education, and other special programs in Connecticut and California. Publicly Owned is set to 1 for centers that are owned and operated by public agencies. Examples include public colleges, hospitals, and city departments of family services. Publicly 
Supported is another dichotomous variable which takes the value of 1 if the center is not publicly owned or operated, but receives more than 50 percent of its revenue from public grants, public fees and USDA reimbursement. Church is equal to 1 if the center has a religious affiliation (e.g. churchbased centers), and zero otherwise.

The variables listed in Table 3 allow for critical tests. For example, adverse selection hypothesis suggests that parents would rely on observable center attributes as signals of quality (Chezum and Wimmer 1997, Genesove 1993). Thus, it will be investigated whether parents take as signals of quality such center characteristics as being for-profit, church-sponsored, publicly owned, etc. These center characteristics also allow us to test the moral hazard hypothesis. For moral hazard to exist two conditions must hold. First, it should be difficult for parents to differentiate high quality centers from low quality ones. Second, some of the center attributes, which can taken be as signals of quality by parents, should be negatively related to unobservable quality. Some of the variables presented in Table 3 are designed to gauge the relationship between parents' perception of quality and certain aspects of the center that may be thought of as reliable proxies of quality. For example, Clean Entrance is a dummy variable which takes the value of 1 if the entrance and the reception area of the center is freshly painted, very organized, and as spotless and shiny as a doctor's office; and zero otherwise. Evidence for the moral hazard hypothesis can be found if, all else being the same, an easily observable characteristic (such as the cleanliness of the reception area) is in fact negatively related to actual difficult-to-observe classroom quality, and parents do not consider this particular characteristic as a negative signal of quality. Two other variables that enable us to test this hypothesis are: Coffee and Cookies and Articulate Director. In the former case, the dummy variable takes the value of 1 if there are amenities at the center pertaining to parents such as free coffee and cookies. In case of the latter variable, data collectors were asked to rate the director's articulateness from 1 (poor) to 5 (very good). Articulate Director is a dummy variable which takes the value of 1 if the director received 5 from data collectors, and zero otherwise. As Table 3 demonstrates, 26 percent of centers offer coffee and cookies to the parents; 27 percent have very clean entrance and reception areas; and 80 percent of the centers have a director who is very articulate. Somewhat surprisingly, these three variables are not highly correlated. The simple correlation between Coffee \& Cookies and Clean Entrance is 0.18. The simple correlation between Coffee \& Cookies and Articulate Director is 0.16, and it is 0.19 between Clean Entrance and Articulate Director. Clean Entrance and Articulate Director may contain measurement error as they necessarily involve a judgement on part of the data collectors. 
These variables will be employed as explanatory (independent) variables in the analyses; thus, measurement error in these variables would generate a bias in their estimated coefficients toward zero (towards finding no impact). The results should be interpreted with this caveat in mind.

\section{Weak Rationality}

Parents' assessment of quality is unbiased if parents do not make systematic errors in their assessment, and on average, they predict the true quality accurately. This notion of unbiased prediction corresponds to weak rationality. Let $P A$ stand for the parent's assessment of a particular aspect of the classroom's operation, and $Q$ be the observer's rating of the same aspect. Following Keane and Runkle (1998), Mocan and Azad (1995), Feenberg et al. (1989) and the literature they cite, a test for weak rationality can be performed by estimating the regression

$$
P A_{k i j}=\beta_{0}+\beta_{1} Q_{i}+\varepsilon_{k i j},
$$

where $\mathrm{PA}_{\mathrm{kij}}$ is the rating of the $k$ th aspect of quality by the $j$ th parent in the $i$ th classroom, $\mathrm{Q}_{\mathrm{i}}$ stands for the rating of the same aspect of quality in classroom $i$, and $\varepsilon_{\mathrm{kij}}$ is the white noise error term that impacts parent's perceptions. Under the hypothesis of weak rationality $\beta_{0}=0$ and $\beta_{1}=1$; that is, parents do not make systematic errors, and predict the true quality on average.

\section{Figure 1:}

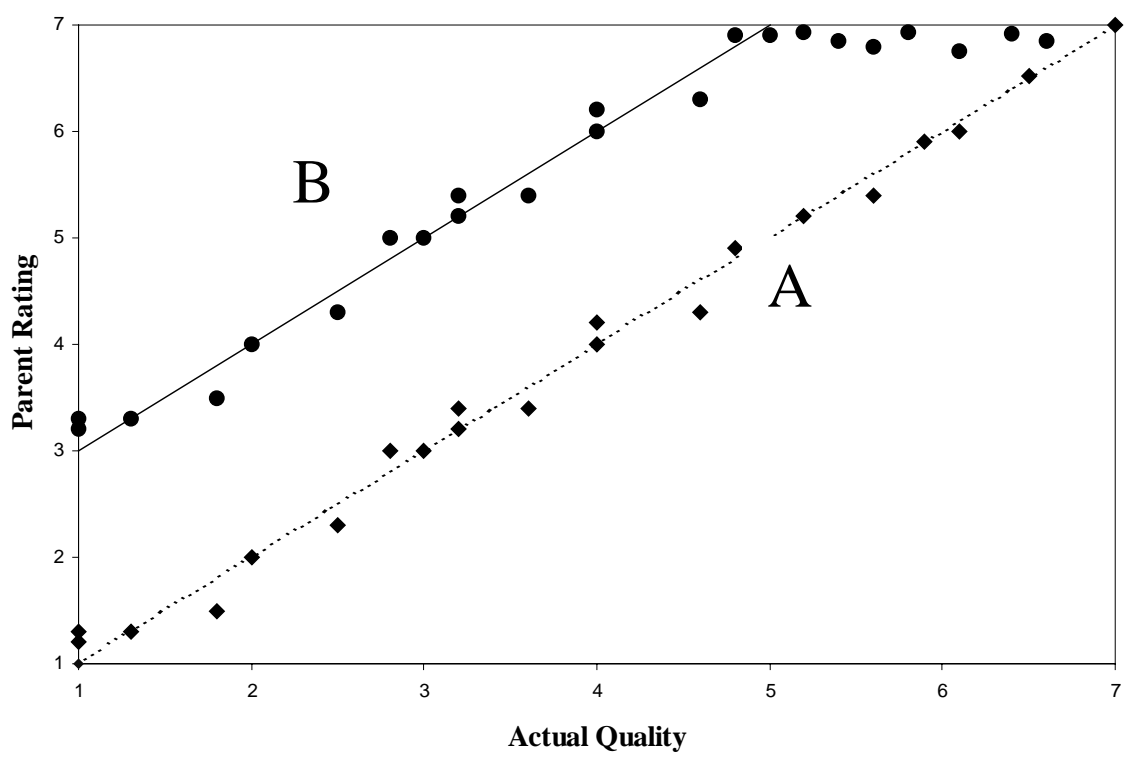


This scenario is represented by points along A in Figure 1. Observer ratings (true quality) are measured on the horizontal axis, and parents' assessment are measured on the vertical axis. Unbiased assessment $\left(\beta_{0}=0, \beta_{1}=1\right)$ implies that the observations should be scattered around the 45 degree line.

Figures 2-7 display parent ratings of selected aspects of the classrooms. The graphs of all other questions, which are not reported in the interest of space, are very similar (see Mocan 2000). As is evident from the graphs, the expert rating-parent rating pairs are not scattered around the 45-degree line. Rather, parents over-estimate actual quality. Figure 2 displays parents' average rating of all the questions given to them as a function of the classroom averages. Figure 3 presents the same information for observable aspects of the classroom quality. Similarly, Figure 4 plots parents' average ratings of the unobservable aspects of classroom quality against experts' rating of the classrooms on the same dimension. ${ }^{6}$

\footnotetext{
${ }^{6}$ Easy-to-observe aspects for infant-toddler include the following: Furniture for Routine Care; Furniture for Play and Learning; Softness in Room; Room Arrangement; Arriving and Leaving Times; Keeping Children Clean and Neat; Talking With Children; Small Muscle Activities; Active Play Activities; Chances for Children to Make Friends; Teacher's Behavior with Children; Discipline; and Daily Schedule.

Difficult-to-observe aspects for infant-toddlers include: Room Decoration; Meals and Snacks; Nap Time; Diapering and Toileting; Healthful Caring; Health Rules; Safe Caring; Safety Rules; Books and Pictures Activities; Art Activities for Toddlers; Music Activities; Activities with Blocks; Pretend Play; Sand and Water Play; and Activities for Different Cultures.

Preschool Observable Quality includes: Arriving and Leaving; Diapering and Toileting; Keeping Children Clean; Furniture for Routine Care; Furniture for Play and Learning; Furnishing for Relaxation and Comfort; Room Arrangement; Room Decoration; Small Muscle Activities; Space for Active Play; How Teacher Supervises Active Play; Pretend Play; Schedule; How Teacher Supervises Play Activities; FreeChoice Play Activities; and How Pleasant the Room Feels.

Preschool Unobservable Quality includes: Meals and Snacks; Nap or Rest Time; Helping Children to Understand Talk; Helping Children Learn to Talk Well; Helping Children Learn to Think and Reason; Teacher's Talking; Supervision of Small Muscle Activities; Equipment for Active Play; Time for Active Play; Art Activities; Music Activities; Block Play; Sand and Water Play; Space for Child to be Alone; Group Times; and Activities About Different Cultures.
} 
Figure 2

Total Quality Score

\section{Parent \\ Rating}

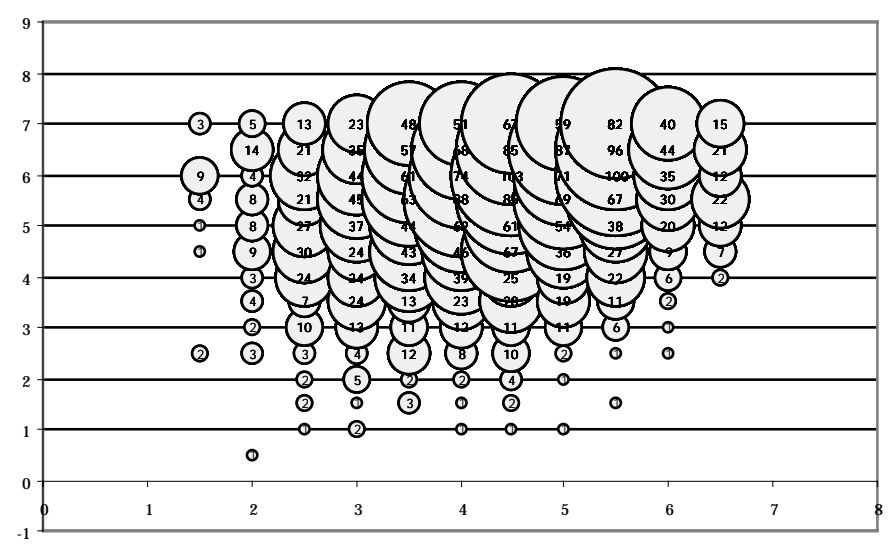

Expert Rating

Figure 3

Total Quality Score for Observable Quality

Parent

Rating

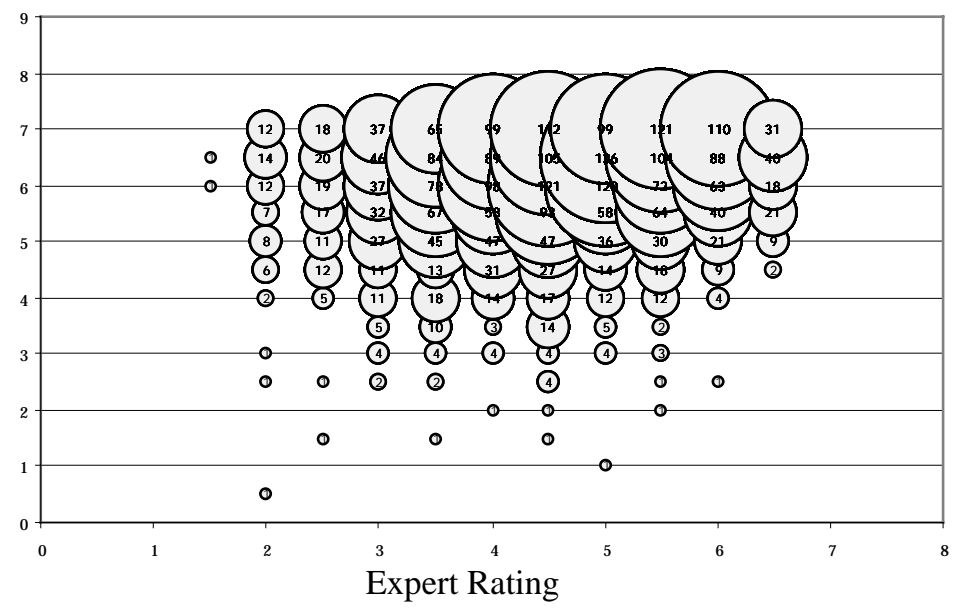

Figure 4

Total Quality Score for Unobservable Quality

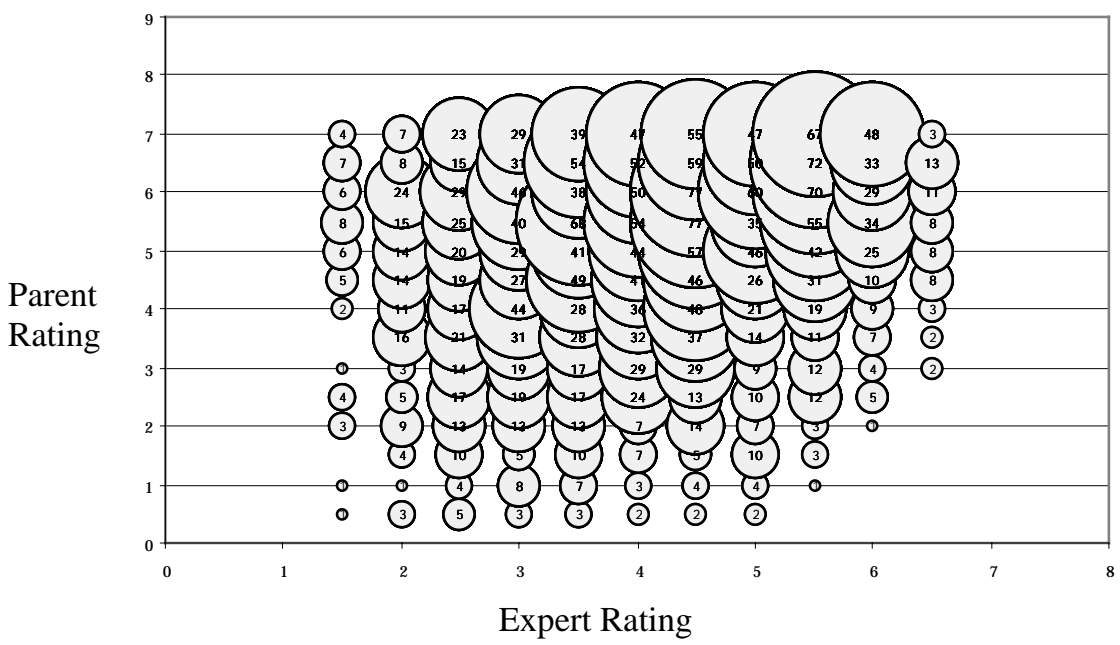


Figure 5

Arriving and Leaving Times

Diapering and Toileting

Talking With Children

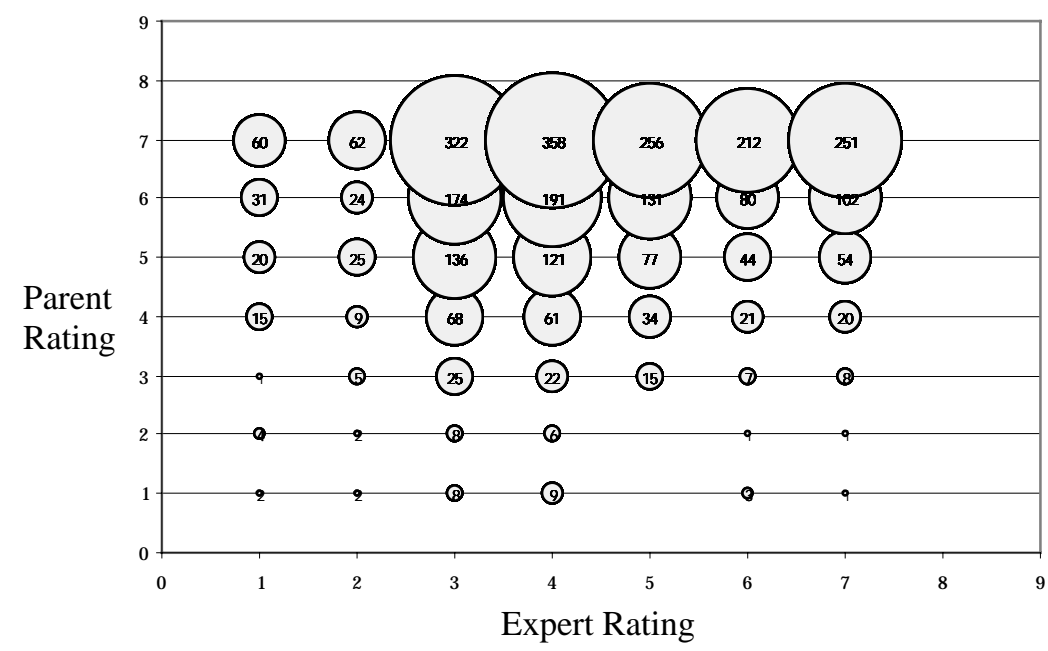

Figure 6

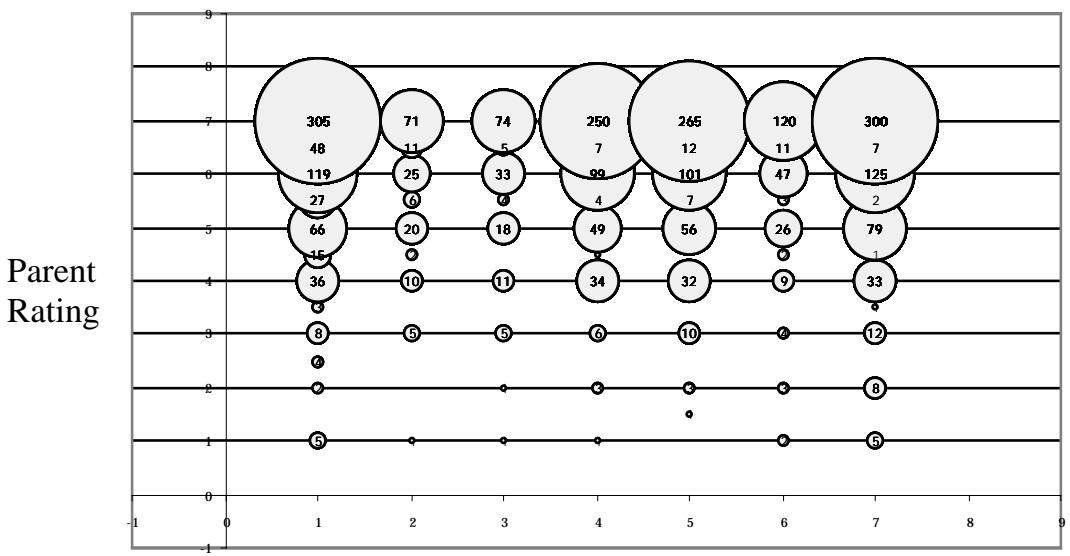

Expert Rating

Figure 7

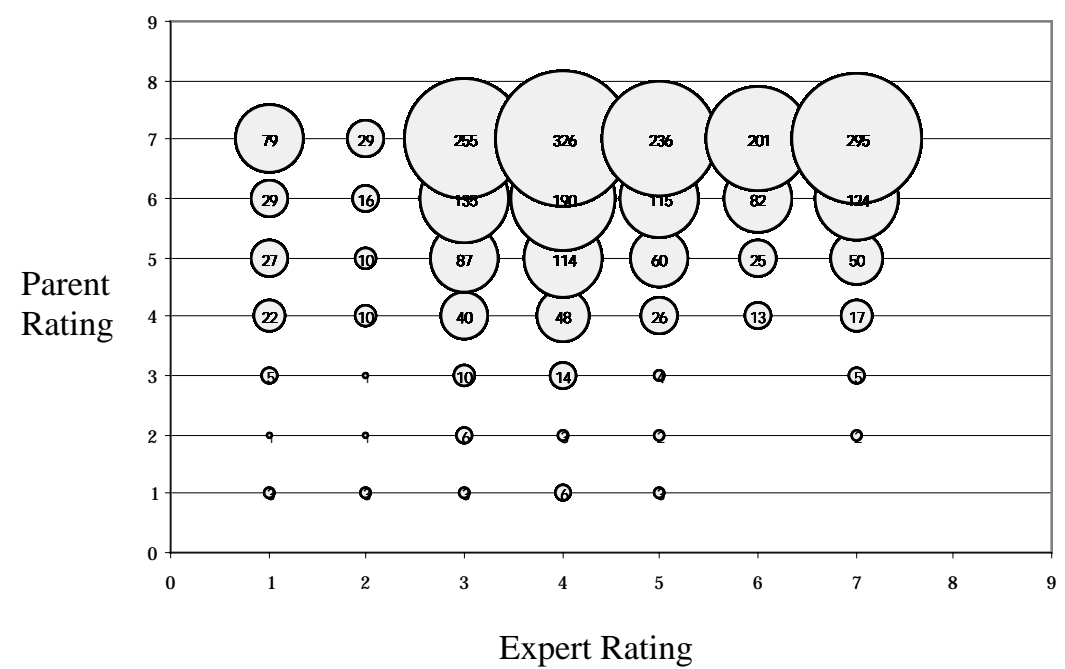


To formally test the hypothesis of weak-rationality, Equation (1) is estimated, and the results are presented in Table App-2 in the Appendix. The point-estimates of the slope parameter $\left(\beta_{1}\right)$ are significantly different from zero in all cases, but they are smaller than one for every question. The F-statistics for the hypotheses of $\beta_{1}=1$, and the joint hypothesis of $\beta_{0}=0$ and $\beta_{1}=1$ are also reported in the tables, and both hypotheses are strongly rejected in each case. This means that parent rating and expert ratings of quality do not have a one-to-one correspondence $\left(\beta_{1} \neq 1\right)$, and they are not scattered around the 45-degree line $\left(\beta_{0} \neq 0\right.$, and $\left.\beta_{1 \neq 1}\right)$, implying that parents are not weakly rational.

\section{Measurement Error}

It can be argued that parent ratings may be noisy, and contaminated with measurement error. This could be because the surveys given to parents are abbreviated versions of the instruments used by observers. Therefore, the condensed nature of the survey (in comparison to the one used by the observers) may have generated noise in parent ratings. However, measurement error in parent ratings (PA) would not yield a bias in the estimated coefficients of $\beta_{0}$ and $\beta_{1}$ as the noise in parent ratings will be absorbed by the error term $\varepsilon$ in Equation (1). On the other hand, because parents had the opportunity to observe the center repeatedly before they were given the questionnaire, it can be argued that their evaluations may be more accurate in comparison to those of the professional evaluators who observed the center only once. This argument suggests that observers' ratings would contain more noise in comparison to that of the parents. ${ }^{7}$ If this kind of random noise in observer rating is prevalent, it would create an attenuation bias for the estimated parameter $\beta_{1}$ of Equation (1), biasing it towards zero. This would mean that one would incorrectly conclude that parent and observer ratings are systematically different. It would be surprising to face the same type of noise in all these questions. Nevertheless, the issue is important and warrants further investigation. To test the potential bias that may have been created by the noise in observer ratings, Equation (1) is

\footnotetext{
${ }^{7}$ For example, consider the question on napping, which includes aspects of the nap schedule, adult supervision and the quality of the nap area. Imagine that the accurate rating of this question is a 5 on the scale from 1 to 7 , and parents who have the opportunity to observe the center repeatedly give this question a rating of 5 on average. Imagine further, that when the trained observers visited the center, it was a "bad" day for whatever reason, and the center received a rating of 4.
} 
reversed and observers' ratings is regressed on parents' ratings. More specifically, Equation (2) below is estimated.

(2) $\quad Q_{k i}=\alpha_{0}+\alpha_{1} P A_{k i j}+u_{k i j}$.

In this specification, even if expert rating $(\mathrm{Q})$ contains significant measurement error, the noise would be absorbed by the error term $\mathrm{u}$, and the parameter $\alpha_{1}$ would remain unbiased. Note that under weak rationality we still expect $\alpha_{0}=0$ and $\alpha_{1}=1$. The results are reported in Table App-3 in the Appendix. As was the case with estimating Equation (1), we strongly reject the hypotheses that and $\alpha_{1}=1$, as well as the joint hypothesis $\alpha_{0}=0$ and $\alpha_{1}=1$. Thus, reverse regression estimates in which actual quality is regressed on parent assessment also lead to the rejection of the weak rationality hypothesis of parents.

\section{Specification Error}

Consider Equation (1) again.

$$
\text { (1) } P A_{k i j}=\beta_{0}+\beta_{1} Q_{k i}+\varepsilon_{k i j} \text {, }
$$

Re-arranging terms and solving for $\mathrm{Q}$ gives

$$
\mathrm{Q}_{\mathrm{ki}}=-\left(\beta_{0} / \beta_{1}\right)+\left(1 / \beta_{1}\right) \mathrm{P} A_{k i j}-\left(1 / \beta_{1}\right) \varepsilon_{\mathrm{kij}},
$$

which is the formulation estimated in Equation (2), where $\alpha_{0}=-\left(\beta_{0} / \beta_{1}\right)$, and $\alpha_{1}=1 / \beta_{1}$. This suggests that if $\beta_{1}<1$ in Equation (1) then it follows that $\alpha_{1}>1$ in Equation (2). However, as is evident in Tables App-2 and App-3, both $\beta_{1}$ and $\alpha_{1}$ are less than 1. This is puzzling, and may suggest that the test of weak rationality as conducted above, although standard and intuitive, may contain a specification bias. This type of contradiction has been noticed in experimental forecast error rationality (Beckman 1992). One possible explanation of this bias can be demonstrated as follows.

Assume that the ratings provided by trained observers are generated by the following mechanism.

$$
\text { (3) } \mathrm{Q}=\mathrm{a}+\mathrm{b} \mathbf{I}+\mathrm{e}_{1} \text {, }
$$

where $\mathbf{I}$ represents the information set utilized by trained observers in creating their ratings, $e_{1}$ is a white noise error term, and $a$ and $b$ are parameters (the subscripts are suppressed for simplicity). I 
consists of various classroom and center characteristics that impact experts' ratings. The same factors are observed by the parents in generating parent ratings. That is,

(4) $\quad \mathrm{PA}=\mathrm{c}+\mathrm{dI}+\mathrm{e}_{2}$.

Solving for I in Equation (3) and substituting in (4) yields

(5) $\quad \mathrm{PA}=\mathrm{c}-(\mathrm{da} / \mathrm{b})+(\mathrm{d} / \mathrm{b}) \mathrm{Q}+\mathrm{u}_{1}, \quad$ where $\mathrm{u}_{1}=-(\mathrm{d} / \mathrm{b}) \mathrm{e}_{1}+\mathrm{e}_{2}$.

Similarly, solving for I in Equation (4) and substituting in (3) yields

(6) $\mathrm{Q}=\mathrm{a}-(\mathrm{bc} / \mathrm{d})+(\mathrm{b} / \mathrm{d}) \mathrm{PA}+\mathrm{u}_{2}, \quad$ where $\mathrm{u}_{2}=-(\mathrm{b} / \mathrm{d}) \mathrm{e}_{2}+\mathrm{e}_{1}$

Note that Equation (5) is the same as Equation (1), where PA is the dependent variable, and $\mathrm{Q}$ is the independent variable. However, in this framework the error term $\mathrm{u}_{1}$ in Equation (5) is negatively correlated with the right-hand side variable $\mathrm{Q}$, generating a downward bias of the estimated coefficient of $\mathrm{Q}$. The same is true for Equation (6), where $\mathrm{u}_{2}$ and PA are negatively correlated through the impact of $e_{2}$. This means that if Equations (3) and (4) represent the correct way of thinking of the manner in which expert ratings and parent rating are formulated, then they provide an explanation as to why the estimated parameter of $\beta_{1}$ in Equation (1) and $\alpha_{1}$ in Equation (2) are both consistently less than 1 .

A solution to this issue is to estimate Equation (1) by Instrumental variables (IV). The literature on child care quality production functions provides guidance on potential instruments. The formulation depicted in Equation (3) is a production function of classroom quality, where I consists of classroom and center characteristics (Blau, 1997; Mocan et al., 1995). Thus, Equation (1) is estimated where $\mathrm{Q}$ is instrumented by the variables listed in Tables 2 and 3, which are: teacher experience, teacher age, percent black teachers, percent white teachers, percent Asian teachers, staff-child ratio, group size, for-profit status, on-site, publicly regulated, publicly supported, publicly owned, church, national chain, percent subsidized children, percent white children, infanttoddler, and state dummies. Because there is evidence of state-specific variation quality as a function of for-profit status, For-profit is interacted with state dummies. This formulation of the quality production function is also used as the benchmark in evaluating the accuracy of parent assessments, as will be explained below.

The IV estimates of the coefficients and the adjusted standard errors are reported in Table 4. The estimated coefficients are larger than those obtained from OLS (Tables App-2), but we still 
reject the hypothesis of weak rationality ${ }^{8}$ I also obtained the IV estimates of the reverse regression (Equation 2), where expert ratings are regressed on parent ratings. The estimated coefficients for the most part were greater than one. For those coefficients that are less than, but close to one (e.g. $0.9)$ the hypothesis that they are greater than one could not be rejected. Thus, the IV estimates of the reverse regressions, which are displayed in Table App-4, provided evidence consistent with the regressions of parent ratings on expert ratings. This means that, even adjusting for endogeneity of the actual quality $(\mathrm{Q})$ employed in Equation (1), we reject the hypothesis that parents are weakly rational, suggesting that parents do not to predict actual quality accurately.

\section{Alternative Hypotheses for Rejection of Weak Rationality}

The reason for the rejection of weak rationality can be because parents' average rating in the sample can be higher than the actual rating assigned by observers, but it can be independent of the actual rating. This hypothesis is rejected because although the estimated coefficients of $Q$ in Equation (1) are smaller than one, they are significantly different from zero. In other words, parent ratings are not independent of actual quality. The two are positively correlated, although the relationship is not as strong as required by weak rationality. Another possibility for the rejection of the hypothesis of weak rationality is that parents operate on a different scale than trained observers. In other words, parents may choose to neglect the lower portion of the scale of 1-7, and they may use only the upper range instead. Their rating may differ from that of the observers such as $\mathrm{PA}=a+\mathrm{Q}$, where $\mathrm{PA}$ is parent rating, $\mathrm{Q}$ is the actual (observer) rating, and $a>0$. In this case, $\beta_{0} \neq 0$, but $\beta_{1}=1$ in equation (1), and one would observe a relationship between parent assessment and true quality such as the one displayed by the dots around line B in Figure 1 given a positive $a$. For example, line B in Figure 1 depicts a situation in which parents overrate quality by 2-points in comparison to trained observers. In this example because the scale has an upper-bound of 7, parent ratings would be equal to 7 when the actual quality is equal to or greater than 5 . The hypothesis that parents use a different scale can be tested by estimating the following equation.

$$
P_{k i j}=\beta_{0}+\beta_{1} Q_{k i}+\gamma D+\delta D Q_{k i}+\varepsilon_{k i j},
$$

where the notation is the same as before, and $\mathrm{D}$ is a dichotomous variable to indicate the threshold level of actual quality, beyond which parent ratings always equal to 7 .

\footnotetext{
${ }^{8}$ The first-stage regressions had explanatory power. The mean R-square of all models was 0.29 .
} 
Equation (7) is estimated to test the hypotheses that parents overrate actual quality by 1,2, 3 or 4 points. For example, if parents overrate by 1-point, $\gamma=1$ and the slope becomes horizontal after actual quality is equal to $6\left[\left(\beta_{1}+\delta\right)=0\right.$ when $\left.Q \geq 6\right]$. If parents overrate by 2-points, $\gamma=2$ and $\left(\beta_{1}+\delta\right)=0$ when actual quality is equal to or greater than 5 , and so on. The models are estimated by Instrumental Variables. For each question given to the parents, using the notation of Equation (7), the following six tests are conducted: (i) $\beta_{1}=1$, (ii) $\beta_{0}=4,3,2$ or 1 , (iii) joint test for (i) and (ii), (iv) $\left(\beta_{1}+\delta\right)=1$, (v) $\left(\beta_{1}+\delta\right)=0$ and (vi) joint test for $(v)$ and $\left(\beta_{0}+\gamma\right)=0$. The first test investigates whether the pre-break slope is equal to one (see line B in Figure 1). The third test is to see if the post-break slope is equal to one, and the fifth test investigates whether the post-slope is zero (such as the horizontal segment of line B in Figure 1). The results, which are not reported in the interest of space, demonstrate that about 70 percent of the time we cannot reject the hypothesis that $\beta_{1}=1$ in the pre-cutoff region. Similarly, for the majority of the questions, we cannot reject the hypothesis that $\left(\beta_{1}+\delta\right)=0$, indicating that after the threshold quality parents assign ratings that become independent of actual quality. (This is the horizontal segment of line B in Figure 1).

\section{Figure 8:}

Predicted Total Quality Values of Colorado Preschool Parents

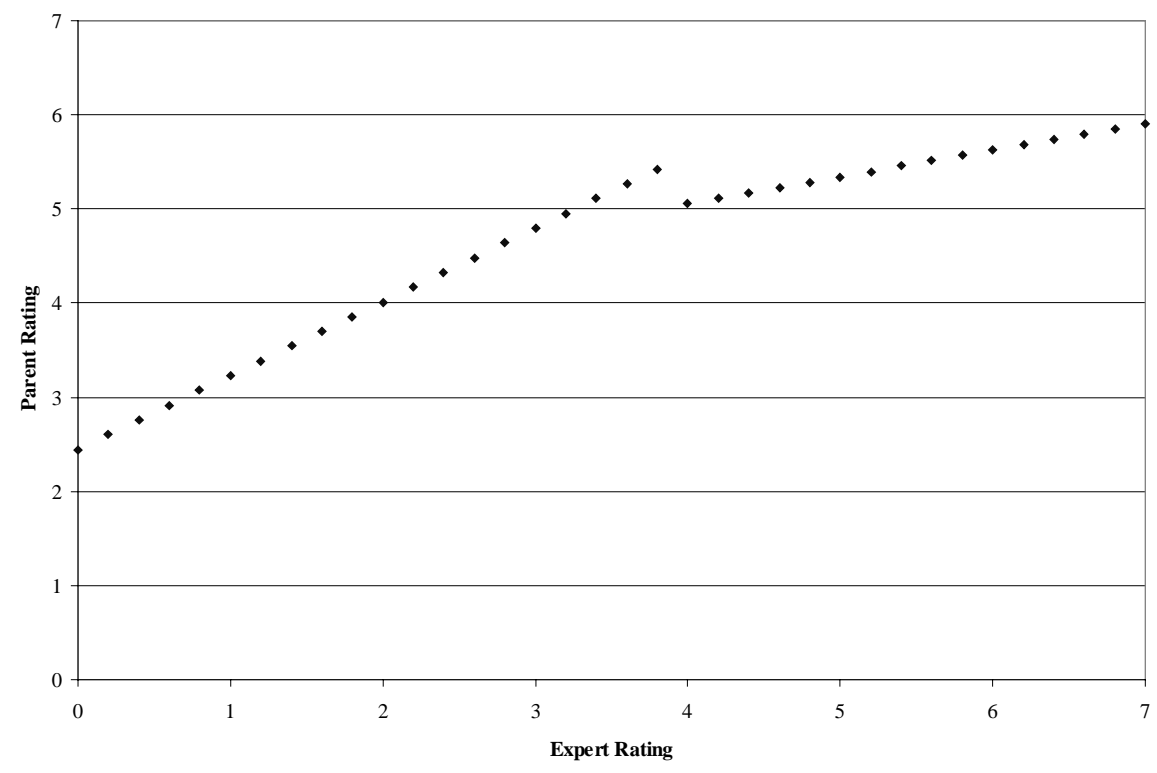

To present this information visually, Figure 8 displays the predicted values of Colorado preschool parents' total quality assessment as a function of actual quality obtained from the IV estimates of Equation (7) with a threshold of actual quality equal to 4. Thus, the analysis performed in this section suggests evidence indicating that parents use a different scale in comparison to trained observers; and adjusting for the scale effect there is evidence for parent weak rationality. 


\section{Strong Rationality:}

Consider equation (9) below.

$$
\mathrm{Q}=f(\mathrm{~S}, \mathrm{R}),
$$

which states that classroom quality, Q, depends on structural room characteristics S, (e.g. staff-child ratio, group size, teacher experience, etc.) and the characteristics of the center, R (e.g. for-profit vs. nonprofit, publicly regulated, publicly owned, percent subsidized children, etc.). Equation (9) is a standard quality production function (e.g. Blau, 1997; Mocan et al., 1995).

Equation (10) below postulates that parents' assessment of center quality (PA) depends on the same factors as in (9).

$$
\mathrm{PA}=h(\mathrm{~S}, \mathrm{R}, \mathrm{Z}) \text {, }
$$

where $\mathrm{Z}$ stands for parent characteristics (e.g. age, race, education, etc.). Thus, equations (9) and (10) are more specific formulations depicted by Equations (3) and (4).

A test for strong rationality of parent assessment of quality can be performed by investigating whether the actual quality $(\mathrm{Q})$ and its assessment by parents (PA) are governed by the same regression relationship. Note that parametization of (9) and (10), and subtracting (10) from (9) yields

$$
P A_{i c j} Q_{i c}=\delta_{0}+\delta_{1} S_{i}+\delta_{2} R_{c}+\delta_{3} Z_{i c}+V_{i c j},
$$

where the subscript $i c j$ represents the $j$ th parent affiliated with the $i$ th room in the $c$ th center.

The left-hand-side of equation (11) is the difference between parent assessment of quality and actual quality, which is the prediction error. A rationality test can be performed by testing the null hypothesis that $\left(\delta_{0}=\delta_{1}=\delta_{2}=0\right)$ in equation (11). That is, classroom and center characteristics should be orthogonal to parental prediction errors. To give an example, if religious centers are of high quality as rated by trained observers in equation (9), and if parents believe that that is the case in equation (10), then the difference between parent rating and observer rating (parent error) in Equation (11) should not depend on religious affiliation of the center. This procedure, which is employed by Mullineax (1978), Feenberg et al. (1989), Mocan and Azad (1995), and Keane and Runkle (1998) is a test of strong rationality. Failure to reject the null hypothesis gives support to strong rationality and implies that parents utilize all available information efficiently in forming their assessments of center quality. 
Estimation of Equation (11) showed that in all cases we strongly reject the hypothesis of strong rationality (Table App-5). This implies that there exists information in the explanatory variables that can be extracted by parents to improve the accuracy of their evaluation.

\section{Determinants of Parent Prediction Error}

Given that the hypothesis of strong rationality is rejected, it is important to investigate the determinants of parents' prediction error. To that end models are estimated where the difference between individual parent ratings and actual quality (parent prediction error) is explained by parent, classroom and center characteristics. Following previous empirical literature on asymmetric information, adverse selection in the market for child care suggests that parents rely on center characteristics as predictors of quality. More precisely, detection of a relationship between parent quality assessment and center attributes (e.g. nonprofit status, being a national chain, or being a publicly owned center) is an indication of adverse selection.

Because the quality scale is bounded from above at seven, and in light of the results presented in section IV, it is reasonable to assume that parent errors are likely to be censored from above. Put differently, some parents who would have liked to assign a higher rating were forced to assign a rating of seven. For such parents the observed prediction errors are smaller than one would have observed otherwise. To account for this potential censoring in the dependent variable, the models are estimated with maximum-likelihood, where censoring in the prediction error is modeled as a function of the actual quality. Alternative censoring levels are investigated for actual quality ranging from 3 to 6 . The likelihood functions were maximized mostly when actual quality was 4.1. Thus, the models are estimated where parent prediction errors are considered as right-censored when the corresponding actual quality is 4.1 or higher (prediction errors are 2.9 or lower).

Table 5 displays the determinants of parent prediction error for total quality, observable (easy-to-observe) quality and unobservable (difficult-to-observe) quality. The results for individual questions are discussed below. Tables 5 pertains to the analysis of positive prediction errors. Therefore, it represents the analyses of parents who over-estimated the true quality of their children's classrooms. Thus, a positive coefficient for a particular variable in the table indicates that an increase in that variable generates an increase in the prediction error. The results for the analysis of negative prediction error were consistent with those of positive error, thus they are not presented 
in the interest of space. As explained above, estimation of quality production functions reveal between-state variation in quality by for-profit status. This means that controlling for all other factors, for-profit centers in a particular state may have higher (or lower) levels of quality in comparison to for-profit centers in a different state. Thus, quality production functions estimated in the paper include state-for-profit interactions. For consistency, the same specification is used in the analyses of parent prediction errors.

To investigate whether low-educated parents react differently to signals coming from centers, the variable High School or Less, which identifies parents who have high school education or less is interacted with Clean Entrance, Articulate Director, and Coffee \& Cookies. Similarly, to test the hypothesis whether parent perceptions of the link between quality and Clean Entrance, Articulate Director, and Coffee \& Cookies differ by profit status, these variables are interacted with For-Profit. Preliminary analysis indicated that the impact of the race-matching is different between minority and white parents. Thus, the variable Same Race is interacted with Minority, where Minority is a dummy variable to identify minority parents.

\section{The Impact of Parent Characteristics}

Table 5 shows that when parents are married, this decreases the prediction error by 0.26 points (on a scale from 1 to 7 ), and each additional child of the family who attends the center increases the prediction error by 0.13 points. Parents whose children receive nine or more hours of care per week are more accurate predictors. This may be because these parents receive more exposure to the center as the child stays longer at the center. Education has a significant impact on parents' prediction error. Parents with at least some college education have more accurate assessments in comparison to parents with high school education or less. This could be because more educated parents are better evaluators of their environment. It could also be because parents who have no high school education may have a poor home environment. Thus, the classroom environment of their children may constitute an improvement in comparison to their home environment, which may lead to a more generous rating for such parents.

Asian parents have more accurate assessments in comparison to parents of other races. An interesting result is the positive and significant coefficient of Same Race* Minority. This means that minority parents' assessment of quality is inflated if the parent and all teachers in the classroom 
are minority. This could be because minority parents prefer their children to be taught by a teacher of the same race; or could simply be a "misplaced trust."

To make sure this result is race-dependent, the models are estimated separately for white parents and for minority parents. The results, which are not reported, provided a striking contrast. The impact of the Same Race variable was zero for white parents, while it was positive and significant for minority parents for total quality, observed quality, as well as unobserved quality. This means that if a classroom consists of all white teachers, this does not impact the quality rating of white parents. On the other hand, if a classroom's teachers consists exclusively of a minority group (Black, Asian, etc.) and if the parent is of the same race, then the parent over-estimates total quality by 0.83 points, observed quality by 0.60 points, and unobserved quality by 0.61 points (see Table 5). Regressions for individual questions revealed that for minority parents a match with teacher race generates an over-estimation in the following items: Furniture for routine care, room decoration, meals and snacks, nap time, talking with children, art activities, pretend play, activities for different cultures, and daily schedule. Six of these nine items are difficult-to-observe.

It is possible that the apparent over-estimation in minority parents' rating as a function of teacher's race is because of some bias in observers' ratings. More specifically, it may be the case that minority parents do not over-estimate the quality when the classroom staff is of the same race, but the observers under-rated all-minority-teacher classrooms in comparison to the classrooms with all-white or mixed-race teachers. Almost all observers who gathered data for this project were white females. Thus, it is not possible to investigate directly the impact of observer race on classroom ratings. However, it is possible to analyze whether classrooms where the staff consists exclusively of minorities received lower observer ratings in comparison to other classrooms, holding constant various standard determinants of quality (such as staff-child ratio, group size, teacher education, etc.). I estimated quality production functions for total quality, observed quality and unobserved quality, which included room and center characteristics, as well as a variable indicating whether the classroom consists of all-minority staff. In no case was the variable representing allminority staff significant. Dropping the race of the teacher from the models and keeping the "all minority staff" variable did not change the results. Thus, there is no evidence of a bias on the part of the observers pertaining to the rating received by all-minority staff classrooms. 


\section{Sources of Information}

It is interesting to note that parents who indicate that they drop in on the classroom unexpectedly tend to over-estimate total quality by 0.27 points, easy-to-observe quality by 0.22 points and difficult-to-observe quality by 0.19 . No other sources of information has a significant impact on parents' prediction error. Interaction of the age group of the child (the Infant-toddler dummy) with variables measuring sources of information did not produce significant coefficients.

\section{Room Characteristics}

The racial composition of classroom teachers has an impact. Keeping the percentage of black and white teachers the same, an increase the percentage of Asian classroom teachers (which implies a switch from Hispanic teachers and teachers of other races to Asian teachers) generates a decrease in parents' over-estimation. Holding the staff-child ratio constant, an increase in group size increases parents' prediction error. To give an example, consider a classroom with 10 children and 2 staff, with a staff-child-ratio of 0.2 . Consider a second arrangement with 20 children and 4 staff. This second room has the same staff-child-ratio, but the group size is larger by 10 . This second arrangement generates an increase in the prediction error by 0.15 points in comparison to the first arrangement. It can be argued that the positive relationship between group size and parents' overrating of total quality is a reflection of parental preferences. That is, parents simply prefer their children to be in larger classrooms as long as the staff-child ratio remains the same. One possible reason for this may be having access to greater choice of social diversity. Another possibility may be concerns over safety of children if larger classrooms promote heightened feelings of security. When the model is estimated separately for each of the 19 questions listed in Table App-1, it is found that the group size had a positive impact on parent prediction error for the following five items: room arrangement, diapering and toileting, small muscle activities, music activities, and activities for different cultures. With the exception of the first, these are unobservable items, confirming that larger group sizes makes parents overrate classroom quality mostly in unobservable dimensions of classroom operation.

\section{Center Characteristics and Signal Extraction}

The results reveal significant signal-extraction from center characteristics, which underscore adverse selection. For example, parents with children at religious centers and at publicly regulated centers have more conservative quality ratings, while publicly supported centers produce 
an over-rating. The proportion of white children at the center is associated with a perception of higher quality, while the proportion of subsidized children generates a lower parent quality rating. If the director of a nonprofit center is very articulate, this increases parent prediction error by 0.31 points for total quality, 0.26 points for easy-to-observe quality, and 0.52 points for difficult-toobserve quality.

\section{Comparison with Production Function Estimates}

The results presented in Table 5 are summarized in Table 6 for total quality, observable quality and unobservable quality. The table displays the relationships between prediction errors and their determinants. A zero in a given cell indicates no statistically significant relationship, a $(+)$ signifies a positive relationship, and a (--) indicates a negative relationship. For example, in the first column of Table 5 we observe that there is a negative relationship between Publicly Regulated and parent perception of quality. This information is presented again in Table 6 with a (--) sign in the first column. Similarly, Table 5 displays a positive relationship between group size and parents' prediction error, which is depicted by a $(+)$ in column I of Table 6 on the Group Size row. Table 6 also displays information on "Reality." The signs $(0,+$, or --) under this column are based upon estimation of standard quality production functions (e.g. Blau 1997; Mocan et al., 1995), where quality (total, observable and unobservable) are explained by staff and center characteristics as explained earlier. More specifically, using observed classrooms as the unit of observation, production functions are estimated using the same explanatory variables that are used in explaining parent perceptions. Parent-specific variables, such as parent age, parent race etc. are not included because quality is measured at the classroom level.

Table 6 allows the comparison of parent perceptions to "reality." For example, column II of Table 6 shows that all else the same, for-profit centers in California and North Carolina have lower total quality scores. On the other hand, column I of Table 6 shows that parents do not consider forprofit status as a signal of quality. Similarly, production function estimates indicate that for-profit national chains, publicly owned and publicly-regulated centers produce higher quality. Parents do not consider the first two of these attributes as signals of quality, and they consider the last one as a negative signal of quality. Similarly, parents believe that a larger group size is associated with higher quality, when group size has no statistically significant impact on total classroom quality. On the other hand, parents do not believe a higher staff-child ratio to be a positive signal for quality, when in 
fact it is associated with higher quality. The shaded cells highlight the mismatched cases between parent beliefs and reality. Similar patterns are detected for observable as well as unobservable quality. For example, as column VI of Table 6 demonstrates, keeping all else constant, for-profit status, being a publicly regulated, publicly supported or publicly owned center, and being a church-sponsored center contain information about difficult-to-observe quality. However, the interpretation of the signals are mostly incorrect.

In addition to the incorrect interpretation of the signals, another source of information problem is the lack of reaction to signals. For example, column II of Table 6 demonstrates that the presence of coffee and cookies, the cleanliness of the reception area or the articulateness of the director are positive signals of total classroom quality in for-profit centers, and an articulate director is a positive quality signal in nonprofit centers. However, parents with high school education or less do not consider these as signals of quality, and parents with more than high school education take only director's articulateness in nonprofit centers as a signal of quality.

One way to summarize Table 6 is to count the center attributes which are related to quality, and compare it to the number of attributes that parents consider as quality signals. For example, there are 14 signals that are provided by the centers and classrooms pertaining to unobservable quality. Parents with a high school education or less do not consider 11 of these as appropriate signals. They interpret 2 of these signals correctly, and one incorrectly. Furthermore, they believe that four additional center characteristics are signals of quality, when they are not (such as: being a publicly supported center and the proportion of white children; see columns V and VI of Table 6). Parents with more than high school education do not consider 8 of these 14 signals. They interpret four signals correctly, and two signals incorrectly. They consider four additional characteristics as signals when they are not. The same pattern of making an attempt, but failing to read signals properly emerges in easy-to-observe and total quality as well.

Table 6 demonstrates that in case of observable quality, there are three center attributes parents believe are related to quality, which are: publicly regulated, church and director's articulateness. The corresponding number is eight for unobservable quality, indicating that parents are trying to extract signals from center characteristics more heavily in case of difficult-to-observe aspects of quality. 
It is also informative to analyze the determinants of parent prediction errors and to compare them to the results obtained from production function estimates for individual questions. As described earlier, Table App-1 displays the 19 questions which were worded identically between ITERS and ECERS. Of these 19 questions 10 are unobservable items, and the remaining 9 are observable. Table 7 displays the summary results obtained from eight unobservable and eight observable items, which depict the same pattern which was seen in Table 6 . That is, parents unsuccessfully are trying to extract signals from center characteristics.

A recent paper investigated the presence of moral hazard in the vehicle inspection market (Hubbard 1998), but there is no research on the analysis of moral hazard in markets with nonprofit firms. It has been argued that the nonprofit sector may be a remedy to the moral hazard problem in markets with information asymmetries. Because nonprofit firms are not expected to exploit the information asymmetry in the market, nonprofit status may act as a "trust signal." (Weisbrod 1988). Some of the results displayed in Table 7 suggest potential moral hazard. Interestingly, as Table 7 demonstrates, the quality production functions reveal that nonprofit centers with very clean entrances have statistically significant lower quality for the following items: talking with children, meals and snacks, music activities and pretend play. Furthermore, although statistically insignificant, the coefficients of Clean Entrance was negative in the quality production functions of nonprofit centers for nap time, small muscle activities, sand and water play, and activities with blocks. Thus, in eight of the 10 difficult-to-observe items there is a negative relationship between extreme cleanliness of the reception area of nonprofit centers and the level of quality of these items, suggesting moral hazard. It should be noted that this negative relationship between cleanliness of the reception area and quality is not detected in easy-to-observe attributes of quality. This result, which is somewhat surprising, provides indication of moral hazard in nonprofit centers.

\section{Prices as Signals of Quality}

There is evidence in the marketing literature that consumers believe that higher prices are associated with higher quality, especially for new products (e.g. Monroe 1973, Buzzell et al. 1972, Gerstner 1985). The economics literature also contains papers on product quality signaling, where prices may serve as signals which differentiate between the available quality levels (e.g. Wolinsky 1983, Shapiro 1982, Milgrom and Roberts 1986). To test this hypothesis, fees paid by parents are 
included into the equations that investigate the determinants of parent prediction error. In no case were the fees significant, indicating that controlling for parent, classroom and center characteristics fees do not contain additional information on quality. This is consistent with Cooper and Ross (1984), who show that factors that limit the entry of firms, such as steeply shaped average cost curves and a relative abundance of informed buyers, improve the revelation property of prices in a competitive environment. The results of this paper and those of Mocan (1997) show that such conditions are not satisfied in child care market, and therefore prices would not convey significant information on quality.

\section{Summary and Conclusions}

This project investigates whether the low quality in the center-based child care market is the result of a market failure due to information asymmetry between child care providers and consumers (parents) regarding the quality of services. The paper uses detailed data collected from 400 child care centers in California, Colorado, Connecticut and North Carolina. They contain information on 228 infant-toddler and 518 preschool classrooms and the characteristics of 3,490 parents. Classroom quality is assessed by trained observers using well-established measures, and individual aspects of services provided for children are classified as difficult-to-observe and easy-toobserve quality. Parents are asked to evaluate quality using the same measures. Analyses are conducted using overall quality scores, individual scores that make up the total score, as well as the ratings for easy-to-observe and difficult-to-observe dimensions of classroom quality.

A comparison of parent and observer ratings indicates that parents significantly overestimate quality. However, a closer look suggests that, adjusting for the scale effect, parent ratings parallel observer ratings fairly closely. Put differently, parents use a different scale than trained observers, and adjusting for that scale effect shows that parent irrationality (parents making systematic errors in prediction and not assessing quality accurately) does not have strong support in the data. On the other hand, we soundly reject the hypothesis that parents utilize all available information when forming their assessments of quality.

If parents cannot evaluate the level of quality of the services provided for their children, they would not be willing to pay a premium for high quality. Because it is costly to produce quality (Mocan 1997), centers will not have an incentive to produce high quality in the absence of the demand for it. Thus, high quality centers cannot exist, generating an adverse selection where the 
market is filled with low quality providers. Evidence is found if consumers associate observable provider characteristics with the quality of services.

The results present strong and interesting evidence on this issue. The analysis of parents' prediction errors demonstrates that parents believe that certain center and room characteristics are indicators of quality. The paper also investigates the determinants of true quality by estimating room-level quality production functions. Comparisons of parent beliefs and the factors that impact classroom quality and its components reveals interesting patterns. For example, parents believe that publicly-regulated centers are associated with lower quality, when production function estimates show that these centers have higher quality. Similarly, parents do not consider publicly-owned status as a positive or negative signal of quality, while these centers actually produce higher levels of quality. These patterns are summarized in Tables 6-7.

The clear evidence that emerges from the project is that: (i) Parents are weakly, but not strongly rational. (ii) Parents are trying to extract quality signals from room and center characteristics. These attempts are, for the most part, unsuccessful. Such results provide evidence for adverse selection in the market. (iii) Parent characteristics, such as education and marital status, impact the accuracy of the predictions. (iv) Parent race, and race-matching with classroom teachers has a significant impact on quality assessment. For example, minority parents have significantly higher quality assessments if the classroom teacher is of the same race, suggesting that racematching between minority parents and teachers generates an unfounded trust for minority parents. This result is not due to trained observers' negative bias towards classrooms with minority teachers. There is no race-matching impact for white parents. (v) Parents' attempts to extract signals are stronger in cases of difficult-to-observe items of quality. (vi) There is some evidence of moral hazard, evidenced by the fact that nonprofit centers with very clean reception areas tend to produce lower levels of quality for difficult-to-observe aspects.

These results indicate that the market for center-based child care has aspects of a "market for lemons." The information asymmetry between the parents and the centers regarding the quality of services forces parents to try to extract signals from observable center and classroom characteristics. These attempts are, for the most part, unsuccessful, as parents associate certain center characteristics with quality when they are not; and they don't read other signals of quality.

This body of evidence suggests that the low average quality of child care is attributable to information asymmetry between the consumer and the producers, and therefore points to specific policy remedies. Given that parents strongly reveal their beliefs on the importance of individual 
items in quality instruments, and given their unsuccessful attempts to extract signals from classroom and center characteristics, making information on quality obtained by expert observers available to parents has the potential of creating a remedy for this market failure. 
Table 1

Descriptive Statistics for Parent Characteristics

\begin{tabular}{|c|c|c|}
\hline Variables & Description & $\begin{array}{c}\text { Mean } \\
\text { (Std. Dev.) }\end{array}$ \\
\hline Age & Age of the parent who filled out the survey & $\begin{array}{l}32.959 \\
(6.173)\end{array}$ \\
\hline Father & $\begin{array}{l}\text { Dummy variable }(=1) \text { if the parent who filled out the } \\
\text { survey is the father, }(=0) \text { otherwise. }\end{array}$ & $\begin{array}{c}0.074 \\
(0.262)\end{array}$ \\
\hline No Subsidy & $\begin{array}{l}\text { Dummy variable }(=1) \text { if the parent receives no child } \\
\text { care subsidy, }(=0) \text { otherwise. }\end{array}$ & $\begin{array}{c}0.778 \\
(0.415)\end{array}$ \\
\hline Married & $\begin{array}{l}\text { Dummy variable (=1) if the parent is married, }(=0) \\
\text { otherwise. }\end{array}$ & $\begin{array}{c}0.720 \\
(0.449)\end{array}$ \\
\hline Two Parents & $\begin{array}{l}\text { Dummy variable (=1) if two-parent household, (=0) } \\
\text { otherwise. }\end{array}$ & $\begin{array}{c}0.743 \\
(0.437)\end{array}$ \\
\hline Children & $\begin{array}{l}\text { The number of children in the family attending this } \\
\text { center }\end{array}$ & $\begin{array}{c}1.255 \\
(0.499)\end{array}$ \\
\hline White & $\begin{array}{l}\text { Dummy variable (=1) if the parent is White, }(=0) \\
\text { otherwise. }\end{array}$ & $\begin{array}{c}0.729 \\
(0.444)\end{array}$ \\
\hline Black & $\begin{array}{l}\text { Dummy variable (=1) if the parent is Black, }(=0) \\
\text { otherwise. }\end{array}$ & $\begin{array}{c}0.099 \\
(0.299)\end{array}$ \\
\hline Hispanic & $\begin{array}{l}\text { Dummy variable }(=1) \text { if the parent is Hispanic, }(=0) \\
\text { otherwise. }\end{array}$ & $\begin{array}{c}0.063 \\
(0.242)\end{array}$ \\
\hline Asian & $\begin{array}{l}\text { Dummy variable (=1) if the parent is Asian, }(=0) \\
\text { otherwise. }\end{array}$ & $\begin{array}{c}0.034 \\
(0.181)\end{array}$ \\
\hline Same Race & $\begin{array}{l}\text { Dummy variable }(=1) \text { if the parent and the classroom } \\
\text { teacher(s) are of the same race, }(=0) \text { otherwise. }\end{array}$ & $\begin{array}{c}0.479 \\
(0.500)\end{array}$ \\
\hline Some College & $\begin{array}{l}\text { Dummy variable }(=1) \text { if the parent took some college } \\
\text { courses but no bachelor's degree, }(=0) \text { otherwise. }\end{array}$ & $\begin{array}{c}0.334 \\
(0.472)\end{array}$ \\
\hline College Plus & $\begin{array}{l}\text { Dummy variable }(=1) \text { if the parent has at least a } \\
\text { bachelor's degree or more, }(=0) \text { otherwise. }\end{array}$ & $\begin{array}{c}0.402 \\
(0.490)\end{array}$ \\
\hline Part Time & $\begin{array}{l}\text { Dummy variable }(=1) \text { if the mother works between } 1 \\
\text { and } 34 \text { hours per week, }(=0) \text { otherwise. }\end{array}$ & $\begin{array}{c}0.189 \\
(0.391)\end{array}$ \\
\hline Full Time & $\begin{array}{l}\text { Dummy variable }(=1) \text { if the mother works } 35 \text { or more } \\
\text { hours per week, }(=0) \text { otherwise. }\end{array}$ & $\begin{array}{l}0.550 \\
(0.498\end{array}$ \\
\hline 9-30 Hours of Care & $\begin{array}{l}\text { Dummy variable }(=1) \text { if the child receives 9-30 hours } \\
\text { of care per week at the center, }(=0) \text { otherwise. }\end{array}$ & $\begin{array}{c}0.244 \\
(0.430)\end{array}$ \\
\hline $31+$ Hours of Care & $\begin{array}{l}\text { Dummy variable }(=1) \text { if the child receives } 31+\text { hours } \\
\text { of care per week at the center, }(=0) \text { otherwise. }\end{array}$ & $\begin{array}{c}0.563 \\
(0.496)\end{array}$ \\
\hline Talk to Teachers & $\begin{array}{l}\text { Dummy variable }(=1) \text { if parent finds out about the } \\
\text { child's care by talking to teachers, }(=0) \text { otherwise. }\end{array}$ & $\begin{array}{c}0.810 \\
(0.392)\end{array}$ \\
\hline Talk to Director & $\begin{array}{l}\text { Dummy variable }(=1) \text { if parent finds out about the } \\
\text { child's care by talking to director, }(=0) \text { otherwise. }\end{array}$ & $\begin{array}{c}0.329 \\
(0.470)\end{array}$ \\
\hline Talk to Other Parents & $\begin{array}{l}\text { Dummy variable }(=1) \text { if parent finds out about the } \\
\text { child's care by talking to other parents, }(=0) \\
\text { otherwise. }\end{array}$ & $\begin{array}{c}0.212 \\
(0.409)\end{array}$ \\
\hline
\end{tabular}




\section{(Table 1 concluded)}

\begin{tabular}{|l|l|c|}
\hline Watch at Drop-off & $\begin{array}{l}\text { Dummy variable (=1) if parent finds out about the } \\
\text { child's care by watching classroom at drop-off and } \\
\text { pick-up times, (=0) otherwise. }\end{array}$ & $\begin{array}{c}0.435 \\
(0.496)\end{array}$ \\
\hline Drop in Unexpectedly & $\begin{array}{l}\text { Dummy variable (=1) if parent finds out about the } \\
\text { child's care by dropping in on classroom } \\
\text { unexpectedly, (=0) otherwise. }\end{array}$ & $\begin{array}{c}0.249 \\
(0.432)\end{array}$ \\
\hline Learn from the Child & $\begin{array}{l}\text { Dummy variable (=1) if parent finds out about the } \\
\text { child's care from what the child says or does, (=0) } \\
\text { otherwise. }\end{array}$ & $\begin{array}{c}0.485 \\
(0.500)\end{array}$ \\
\hline Infant-Toddler & $\begin{array}{l}\text { Dummy variable (=1) if the child of the parent is an } \\
\text { infant/toddler, (=0) otherwise. }\end{array}$ & $\begin{array}{c}0.275 \\
(0.447)\end{array}$ \\
\hline & & $\mathrm{n}=2,913-3,490$ \\
\hline
\end{tabular}


Table 2

Classroom Characteristics

\begin{tabular}{|c|c|c|}
\hline Variables & Description & $\begin{array}{c}\text { Mean } \\
\text { (Std. Dev.) }\end{array}$ \\
\hline Teacher Age & Average age of the teachers in the classroom & $\begin{array}{c}35.092 \\
(11.481)\end{array}$ \\
\hline Teacher Experience & $\begin{array}{l}\text { Average experience (in years) of teachers in the } \\
\text { classroom }\end{array}$ & $\begin{array}{c}9.340 \\
(6.839)\end{array}$ \\
\hline $\begin{array}{l}\text { Percent Black } \\
\text { Teachers }\end{array}$ & $\begin{array}{l}\text { Proportion of teachers who are Black in the observed } \\
\text { classroom. }\end{array}$ & $\begin{array}{c}0.179 \\
(0.375)\end{array}$ \\
\hline $\begin{array}{l}\text { Percent White } \\
\text { Teachers }\end{array}$ & $\begin{array}{l}\text { Proportion of teachers who are White in the observed } \\
\text { classroom. }\end{array}$ & $\begin{array}{c}0.628 \\
(0.463)\end{array}$ \\
\hline $\begin{array}{l}\text { Percent Hispanic } \\
\text { Teachers }\end{array}$ & $\begin{array}{l}\text { Proportion of teachers who are Hispanic in the observed } \\
\text { classroom. }\end{array}$ & $\begin{array}{c}0.121 \\
(0.135)\end{array}$ \\
\hline $\begin{array}{l}\text { Percent Asian } \\
\text { Teachers }\end{array}$ & $\begin{array}{l}\text { Proportion of teachers who are Asian in the observed } \\
\text { classroom. }\end{array}$ & $\begin{array}{c}0.022 \\
(0.140)\end{array}$ \\
\hline $\begin{array}{l}\text { Group Size } \\
\text { For IT Rooms }\end{array}$ & $\begin{array}{l}\text { Average group size (the size of the classroom) in infant- } \\
\text { toddler rooms. }\end{array}$ & $\begin{array}{l}9.247 \\
(4.608)\end{array}$ \\
\hline $\begin{array}{l}\text { Group Size } \\
\text { For PS Rooms }\end{array}$ & $\begin{array}{l}\text { Average group size (the size of the classroom) in } \\
\text { preschool rooms. }\end{array}$ & $\begin{array}{l}13.733 \\
(7.104)\end{array}$ \\
\hline $\begin{array}{l}\text { Staff-Child Ratio For } \\
\text { IT Rooms }\end{array}$ & Average staff-child ratio in infant-toddler rooms. & $\begin{array}{c}0.252 \\
(0.166)\end{array}$ \\
\hline $\begin{array}{l}\text { Staff-Child Ratio For } \\
\text { PS Rooms }\end{array}$ & Average staff-child ratio in preschool rooms. & $\begin{array}{l}0.160 \\
(0.105)\end{array}$ \\
\hline & & $\mathrm{n}=633-732$ \\
\hline
\end{tabular}

IT: Infant-toddler, PS: Preschool 
Table 3

Center Characteristics

\begin{tabular}{|c|c|c|}
\hline Variables & Description & $\begin{array}{l}\text { Mean } \\
\text { (Std. Dev.) }\end{array}$ \\
\hline California & Dummy variable $(=1)$ if the center is in California. & $\begin{array}{c}0.249 \\
(0.433) \\
\end{array}$ \\
\hline Colorado & Dummy variable $(=1)$ if the center is in Colorado. & $\begin{array}{c}0.249 \\
(0.433)\end{array}$ \\
\hline Connecticut & Dummy variable $(=1)$ if the state is in Connecticut. & $\begin{array}{c}0.252 \\
(0.435)\end{array}$ \\
\hline $\begin{array}{l}\text { Percent Subsidized } \\
\text { Children }\end{array}$ & The proportion of subsidized children at the center & $\begin{array}{c}0.212 \\
(0.320)\end{array}$ \\
\hline Percent White Children & The proportion of white children at the center & $\begin{array}{c}70.186 \\
(30.218)\end{array}$ \\
\hline For-Profit & Dummy variable $(=1)$ if the center is for-profit. & $\begin{array}{c}0.504 \\
(0.501)\end{array}$ \\
\hline On-Site & $\begin{array}{l}\text { Dummy variable }(=1) \text { if the center is a worksite child care } \\
\text { center. }\end{array}$ & $\begin{array}{c}0.038 \\
(0.190)\end{array}$ \\
\hline Church & Dummy variable $(=1)$ if the center is church-sponsored & $\begin{array}{c}0.195 \\
(0.397)\end{array}$ \\
\hline National Chain & $\begin{array}{l}\text { Dummy variable }(=1) \text { if the center is a member of a national } \\
\text { chain. }\end{array}$ & $\begin{array}{c}0.120 \\
(0.326)\end{array}$ \\
\hline Publicly Supported & $\begin{array}{l}\text { Dummy variable }(=1) \text { if center is not publicly owned or } \\
\text { operated, but receives more than } 50 \text { percent of its revenue from } \\
\text { public grants, fees and USDA reimbursement, }(=0) \text { otherwise. }\end{array}$ & $\begin{array}{c}0.115 \\
(0.320)\end{array}$ \\
\hline Publicly Owned & $\begin{array}{l}\text { Dummy variable }(=1) \text { if center is publicly owned and operated, } \\
(=0) \text { otherwise. }\end{array}$ & $\begin{array}{c}0.068 \\
(0.251)\end{array}$ \\
\hline Publicly Regulated & $\begin{array}{l}\text { Dummy variable }(=1) \text { if center receives public money tied to } \\
\text { higher standards, }(=0) \text { otherwise. }\end{array}$ & $\begin{array}{c}0.070 \\
(0.256)\end{array}$ \\
\hline Coffee \& Cookies & $\begin{array}{l}\text { Dummy variable }(=1) \text { if there are amenities at the center } \\
\text { pertaining to parents such as free coffee and cookies, or a } \\
\text { library. }\end{array}$ & $\begin{array}{c}0.260 \\
(0.439)\end{array}$ \\
\hline Clean Entrance & $\begin{array}{l}\text { Dummy variable }(=1) \text { if the entrance and the reception area of } \\
\text { the center is freshly painted, very organized, and as spotless } \\
\text { and shiny as a doctor's office; }(=0) \text { otherwise }\end{array}$ & $\begin{array}{c}0.274 \\
(0.447)\end{array}$ \\
\hline Articulate Director & $\begin{array}{l}\text { Dummy variable }(=1) \text { if the director is very articulate, }(=0) \\
\text { otherwise. }\end{array}$ & $\begin{array}{c}0.805 \\
(0.396)\end{array}$ \\
\hline & & $\mathrm{n}=399$ \\
\hline
\end{tabular}


Table 4

Weak Rationality, IV Estimates

\begin{tabular}{|c|c|c|c|c|c|c|}
\hline \multirow[b]{2}{*}{ Variables } & \multirow[b]{2}{*}{ Slope } & \multirow[b]{2}{*}{ Std. Err. } & \multicolumn{2}{|c|}{ Ho: $\beta_{1}=1$} & \multicolumn{2}{|c|}{ Ho: $\beta_{0}=\mathbf{0}, \beta_{1}=1$} \\
\hline & & & $F$-value & $p$-value & $F$-value & $p$-value \\
\hline Furniture for Routine Care & 0.009 & $(0.047)$ & 449.20 & 0.000 & 487.51 & 0.000 \\
\hline Furniture for Play and Learning & $0.059 * *$ & $(0.029)$ & 1083.93 & 0.000 & 2001.68 & 0.000 \\
\hline Softness in Room & $0.307 * * *$ & $(0.062)$ & 125.20 & 0.000 & 238.74 & 0.000 \\
\hline Room Arrangement & $0.182 * * *$ & $(0.042)$ & 385.63 & 0.000 & 615.06 & 0.000 \\
\hline Room Decoration & $0.151 * * *$ & $(0.055)$ & 234.57 & 0.000 & 662.24 & 0.000 \\
\hline Arriving and Leaving Times & $0.118 * * *$ & $(0.035)$ & 636.85 & 0.000 & 781.99 & 0.000 \\
\hline Meals and Snacks & $0.525 * * *$ & $(0.088)$ & 29.46 & 0.000 & 93.44 & 0.000 \\
\hline Nap Time & 0.060 & $(0.086)$ & 119.71 & 0.000 & 95.97 & 0.000 \\
\hline Diapering and Toileting & 0.097 & $(0.068)$ & 176.26 & 0.000 & 480.93 & 0.000 \\
\hline Keeping Children Clean and Neat & 0.088 & $(0.097)$ & 88.34 & 0.000 & 370.43 & 0.000 \\
\hline Talking with Children & $0.427 * * *$ & $(0.063)$ & 81.45 & 0.000 & 105.18 & 0.000 \\
\hline Small Muscle Activities & $0.496 * * *$ & $(0.068)$ & 55.11 & 0.000 & 39.54 & 0.000 \\
\hline Art Activities for Children & $0.272 * * *$ & $(0.058)$ & 158.07 & 0.000 & 197.55 & 0.000 \\
\hline Music Activities & $0.510 * * *$ & $(0.098)$ & 24.93 & 0.000 & 13.22 & 0.000 \\
\hline Activities with Blocks & $0.381 * * *$ & $(0.071)$ & 75.89 & 0.000 & 54.12 & 0.000 \\
\hline Pretend Play & $0.659 * * *$ & $(0.103)$ & 10.97 & 0.000 & 144.93 & 0.000 \\
\hline Sand and Water Play & $0.444 * * *$ & $(0.080)$ & 48.33 & 0.000 & 24.22 & 0.000 \\
\hline Activities for Different Cultures & $0.488 * * *$ & $(0.072)$ & 50.16 & 0.000 & 74.78 & 0.000 \\
\hline Daily Schedule & $0.151 * * *$ & $(0.041)$ & 424.28 & 0.000 & 538.42 & 0.000 \\
\hline Total Quality Score & $0.382 * * *$ & $(0.048)$ & 167.96 & 0.000 & 383.38 & 0.000 \\
\hline Total Quality Score for Observable & & & & & & \\
\hline Characteristics & $0.355 * * *$ & $(0.046)$ & 197.25 & 0.000 & 536.25 & 0.000 \\
\hline Total Quality Score for Unobservable & & & & & & \\
\hline Characteristics & $0.406 * * *$ & $(0.052)$ & 128.56 & 0.000 & 241.71 & 0.000 \\
\hline Observable Quality Score-1 & $0.249 * * *$ & $(0.040)$ & 361.41 & 0.000 & 979.34 & 0.000 \\
\hline Unobservable Quality Score-1 & $0.514 * * *$ & $(0.062)$ & 62.32 & 0.000 & 104.77 & 0.000 \\
\hline
\end{tabular}

* indicates statistical significance between $10 \%$ and $5 \%$; ** indicates statistical significance between $5 \%$ (inclusive) and 1\%; *** indicates statistical significance at the $1 \%$ level or better. 
Table 5

Determinants of Prediction Error

\begin{tabular}{|c|c|c|c|c|c|c|}
\hline \multirow[b]{2}{*}{ Variables } & \multicolumn{2}{|c|}{ Total Quality } & \multicolumn{2}{|c|}{ Observable Quality } & \multicolumn{2}{|c|}{ Unobservable Quality } \\
\hline & Coeff. & Std. err. & Coeff. & Std. err. & Coeff. & Std. err. \\
\hline \multicolumn{7}{|l|}{ Parent Characteristics } \\
\hline Age & 0.002 & $(0.006)$ & 0.0003 & $(0.005)$ & 0.010 & $(0.007)$ \\
\hline Father & -0.017 & $(0.120)$ & -0.064 & $(0.102)$ & -0.118 & $(0.144)$ \\
\hline White & -0.108 & $(0.166)$ & -0.008 & $(0.144)$ & -0.139 & $(0.199)$ \\
\hline Black & -0.208 & $(0.181)$ & 0.008 & $(0.158)$ & -0.049 & $(0.222)$ \\
\hline Hispanic & -0.150 & $(0.190)$ & -0.135 & $(0.163)$ & 0.088 & $(0.233)$ \\
\hline Asian & $-0.434 *$ & $(0.239)$ & $-0.482 * *$ & $(0.199)$ & -0.229 & $(0.297)$ \\
\hline Same Race & -0.103 & $(0.154)$ & -0.018 & $(0.132)$ & -0.051 & $(0.188)$ \\
\hline Same Race * Minority & $0.827 * * *$ & $(0.283)$ & $0.595 * *$ & $(0.241)$ & $0.605^{*}$ & $(0.344)$ \\
\hline Married & $-0.260^{*}$ & $(0.140)$ & $-0.207 *$ & $(0.124)$ & -0.176 & $(0.165)$ \\
\hline Two Parents & 0.103 & $(0.141)$ & 0.024 & $(0.124)$ & 0.026 & $(0.165)$ \\
\hline Children & $0.126 * *$ & $(0.057)$ & 0.069 & $(0.051)$ & $0.128 *$ & $(0.070)$ \\
\hline Part Time & 0.005 & $(0.110)$ & 0.015 & $(0.096)$ & -0.027 & $(0.133)$ \\
\hline Full Time & -0.046 & $(0.098)$ & -0.030 & $(0.085)$ & -0.076 & $(0.120)$ \\
\hline 9-30 Hours of Care & $-0.256^{* *}$ & $(0.127)$ & $-0.237 * *$ & $(0.111)$ & $-0.270 *$ & $(0.153)$ \\
\hline 31+ Hours of Care & $-0.199 *$ & $(0.118)$ & $-0.232 * *$ & $(0.104)$ & -0.123 & $(0.142)$ \\
\hline No Subsidy & -0.047 & $(0.089)$ & -0.014 & $(0.078)$ & -0.106 & $(0.107)$ \\
\hline Some College & -0.196 & $(0.169)$ & 0.061 & $(0.141)$ & -0.327 & $(0.210)$ \\
\hline College Plus & $-0.294 *$ & $(0.176)$ & -0.068 & $(0.147)$ & $-0.508 * *$ & $(0.218)$ \\
\hline \multicolumn{7}{|l|}{ Sources of Information } \\
\hline Talk to Teachers & -0.029 & $(0.080)$ & 0.027 & $(0.069)$ & -0.040 & $(0.097)$ \\
\hline Talk to Director & 0.042 & $(0.072)$ & -0.017 & $(0.062)$ & 0.045 & $(0.087)$ \\
\hline Talk to Other Parents & 0.085 & $(0.091)$ & 0.117 & $(0.079)$ & 0.109 & $(0.111)$ \\
\hline Talk at Drop-off & -0.048 & $(0.073)$ & $-0.110 *$ & $(0.063)$ & -0.120 & $(0.090)$ \\
\hline Drop in Unexpectedly & $0.268 * * *$ & $(0.077)$ & $0.221 * * *$ & $(0.067)$ & $0.194 * *$ & $(0.093)$ \\
\hline Learn from the Child & -0.065 & $(0.072)$ & -0.042 & $(0.063)$ & 0.058 & $(0.089)$ \\
\hline \multicolumn{7}{|l|}{ Center Characteristics } \\
\hline For-Profit & -0.024 & $(0.197)$ & 0.057 & $(0.168)$ & -0.003 & $(0.243)$ \\
\hline On-Site & 0.072 & $(0.231)$ & -0.091 & $(0.199)$ & 0.086 & $(0.269)$ \\
\hline Church & $-0.245^{* *}$ & $(0.113)$ & $-0.182 *$ & $(0.099)$ & $-0.258^{*}$ & $(0.136)$ \\
\hline National Chain & -0.113 & $(0.108)$ & -0.132 & $(0.095)$ & -0.128 & $(0.132)$ \\
\hline Publicly Supported & $0.400 * *$ & $(0.175)$ & 0.052 & $(0.153)$ & $0.523 * *$ & $(0.211)$ \\
\hline Publicly Owned & 0.334 & $(0.206)$ & 0.064 & $(0.181)$ & $0.434 *$ & $(0.252)$ \\
\hline Publicly Regulated & $-0.385 * *$ & $(0.190)$ & $-0.297 *$ & $(0.172)$ & $-0.393^{*}$ & $(0.229)$ \\
\hline California * For-Profit & -0.213 & $(0.177)$ & $-0.265^{*}$ & $(0.153)$ & -0.007 & $(0.218)$ \\
\hline Colorado $*$ For-Profit & 0.139 & $(0.176)$ & 0.093 & $(0.151)$ & 0.163 & $(0.218)$ \\
\hline Connecticut * For-Profit & 0.065 & $(0.169)$ & 0.018 & $(0.149)$ & -0.092 & $(0.203)$ \\
\hline Percent White Children & $0.003 *$ & $(0.002)$ & 0.002 & $(0.001)$ & $0.006 * * *$ & $(0.002)$ \\
\hline Percent Subsidized Children & $-0.419 * *$ & $(0.213)$ & -0.005 & $(0.190)$ & -0.354 & $(0.257)$ \\
\hline Coffee \& Cookies & 0.062 & $(0.153)$ & 0.051 & $(0.136)$ & -0.011 & $(0.177)$ \\
\hline Clean Entrance & 0.088 & $(0.109)$ & 0.060 & $(0.096)$ & 0.009 & $(0.131)$ \\
\hline
\end{tabular}


(Table 5 concluded)

\begin{tabular}{|c|c|c|c|c|c|c|}
\hline Articulate Director & $0.312 * *$ & $(0.139)$ & $0.256 * *$ & $(0.119)$ & $0.523 * * *$ & $(0.172)$ \\
\hline Coffee \& Cookies $*$ HS or Less & -0.009 & $(0.192)$ & -0.192 & $(0.168)$ & 0.148 & $(0.229)$ \\
\hline Clean Entrance $*$ HS or Less & 0.005 & $(0.171)$ & -0.033 & $(0.149)$ & -0.046 & $(0.204)$ \\
\hline Articulate Director $*$ HS or Less & -0.060 & $(0.191)$ & 0.210 & $(0.162)$ & -0.298 & $(0.237)$ \\
\hline Coffee \& Cookies $*$ For-Profit & -0.145 & $(0.178)$ & -0.127 & $(0.157)$ & -0.207 & $(0.209)$ \\
\hline Clean Entrance $*$ For-Profit & 0.059 & $(0.139)$ & 0.034 & $(0.122)$ & 0.199 & $(0.167)$ \\
\hline $\begin{array}{c}\text { Articulate Director * For-Profit } \\
\text { Room Characteristics }\end{array}$ & -0.262 & $(0.178)$ & -0.144 & $(0.153)$ & $-0.365^{*}$ & $(0.219)$ \\
\hline Teacher Age & 0.001 & $(0.003)$ & -0.002 & $(0.003)$ & 0.003 & $(0.004)$ \\
\hline Percent Black Teachers & -0.150 & $(0.146)$ & $-0.290 * *$ & $(0.124)$ & 0.048 & $(0.184)$ \\
\hline Percent White Teachers & 0.227 & $(0.168)$ & 0.156 & $(0.146)$ & 0.204 & $(0.206)$ \\
\hline Percent Asian Teachers & $-0.595 * * *$ & $(0.226)$ & $-0.645 * * *$ & $(0.190)$ & $-0.914 * * *$ & $(0.267)$ \\
\hline Teacher Experience & $0.018 * * *$ & $(0.006)$ & $0.017 * * *$ & $(0.005)$ & 0.010 & $(0.007)$ \\
\hline Group Size & $0.015 * * *$ & $(0.005)$ & 0.007 & $(0.005)$ & $0.017 * *$ & $(0.007)$ \\
\hline Staff-Child Ratio & -0.352 & $(0.373)$ & -0.463 & $(0.326)$ & -0.193 & $(0.458)$ \\
\hline Infant Toddler & $0.258 * * *$ & $(0.080)$ & $0.119 *$ & $(0.070)$ & $0.443 * * *$ & $(0.096)$ \\
\hline California & $0.328 * *$ & $(0.158)$ & 0.084 & $(0.137)$ & $0.601 * * *$ & $(0.192)$ \\
\hline Colorado & -0.026 & $(0.146)$ & $-0.238 *$ & $(0.125)$ & 0.207 & $(0.181)$ \\
\hline Connecticut & $0.246^{*}$ & $(0.128)$ & 0.167 & $(0.111)$ & $0.387 * *$ & $(0.154)$ \\
\hline Constant & $1.972 * * *$ & $(0.407)$ & $2.417 * * *$ & $(0.354)$ & $1.376 * * *$ & $(0.494)$ \\
\hline $\mathrm{n}$ & \multicolumn{2}{|c|}{1853} & \multicolumn{2}{|c|}{2013} & \multicolumn{2}{|c|}{1607} \\
\hline Log-Likelihood & \multicolumn{2}{|c|}{-1474.678} & \multicolumn{2}{|c|}{-1402.919} & \multicolumn{2}{|c|}{-1418.750} \\
\hline
\end{tabular}


Table 6

Summary of the Results

\begin{tabular}{|c|c|c|c|c|c|c|}
\hline \multirow[b]{2}{*}{ Variables } & \multicolumn{2}{|c|}{ Total Quality } & \multicolumn{2}{|c|}{ Observable Quality } & \multicolumn{2}{|c|}{ Unobservable Quality } \\
\hline & $\begin{array}{l}\text { Parent } \\
\text { Perception } \\
\text { (I) }\end{array}$ & $\begin{array}{c}\text { Reality } \\
\text { (II) }\end{array}$ & $\begin{array}{l}\text { Parents' } \\
\text { Perception } \\
\text { (III) }\end{array}$ & $\begin{array}{c}\text { Reality } \\
\text { (IV) }\end{array}$ & $\begin{array}{l}\text { Parent's } \\
\text { Perception } \\
\text { (V) }\end{array}$ & $\begin{array}{c}\text { Reality } \\
\text { (VI) }\end{array}$ \\
\hline \multicolumn{7}{|c|}{ Selected Classroom and Center Characteristics } \\
\hline For-Profit, California & 0 & -- & 0 & -- & 0 & -- \\
\hline For-Profit, Colorado & 0 & 0 & 0 & 0 & 0 & 0 \\
\hline For-Profit, Connecticut & 0 & 0 & 0 & 0 & 0 & 0 \\
\hline For-Profit, North-Carolina & 0 & -- & 0 & -- & 0 & -- \\
\hline Publicly Regulated & -- & + & -- & + & -- & + \\
\hline Church & -- & -- & -- & -- & -- & -- \\
\hline National Chain & 0 & + & 0 & + & 0 & 0 \\
\hline Publicly Supported & 0 & 0 & 0 & 0 & + & 0 \\
\hline Publicly Owned & 0 & + & 0 & + & + & + \\
\hline On-Site & 0 & 0 & 0 & 0 & 0 & 0 \\
\hline Percent White Children & + & 0 & 0 & + & + & 0 \\
\hline Percent Subsidized Children & -- & -- & 0 & -- & 0 & -- \\
\hline Percent Black Teachers & 0 & + & -- & + & 0 & + \\
\hline Percent White Teachers & 0 & 0 & 0 & 0 & 0 & + \\
\hline Percent Asian Teachers & -- & 0 & -- & 0 & -- & 0 \\
\hline Teacher Age & 0 & 0 & 0 & 0 & 0 & 0 \\
\hline Teacher Experience & + & + & + & 0 & 0 & + \\
\hline Staff-Child Ratio & 0 & + & 0 & + & 0 & + \\
\hline Group Size & + & 0 & 0 & 0 & + & 0 \\
\hline \multicolumn{7}{|c|}{ Parents with More Than High School Education } \\
\hline Coffee \& Cookies, Nonprofit & 0 & 0 & 0 & 0 & 0 & 0 \\
\hline Clean Entrance, Nonprofit & 0 & 0 & 0 & 0 & 0 & 0 \\
\hline Articulate Director, Nonprofit & + & + & + & + & + & + \\
\hline Coffee \& Cookies, For-Profit & 0 & + & 0 & + & -- & + \\
\hline Clean Entrance, For-Profit & 0 & + & 0 & + & + & + \\
\hline Articulate Director, For-Profit & 0 & + & 0 & 0 & 0 & + \\
\hline \multicolumn{7}{|c|}{ Parents with High School Education or Less } \\
\hline Coffee \& Cookies, Nonprofit & 0 & 0 & 0 & 0 & 0 & 0 \\
\hline Clean Entrance, Nonprofit & 0 & 0 & 0 & 0 & 0 & 0 \\
\hline Articulate Dir., Nonprofit & 0 & + & + & + & 0 & + \\
\hline Coffee \& Cookies, For-Profit & 0 & + & 0 & + & 0 & + \\
\hline Clean Entrance, For-Profit & 0 & + & 0 & + & 0 & + \\
\hline Articulate Director, For-Profit & 0 & + & + & 0 & 0 & + \\
\hline
\end{tabular}

The signs in the cells represent the direction of the relationship between the variable and the parents' perception as well as actual classroom quality. 
Table 7

Summary of the Results for Individual Questions

\begin{tabular}{|c|c|c|c|c|c|c|c|c|c|c|c|c|}
\hline \multirow[b]{2}{*}{ Variable } & \multicolumn{3}{|c|}{ Talking w/ Children } & \multicolumn{3}{|c|}{ Diapering and Toileting } & \multicolumn{3}{|c|}{ Nap Time } & \multicolumn{3}{|c|}{ Meals and Snacks } \\
\hline & $\begin{array}{l}\text { High } \\
\text { Educ. }\end{array}$ & $\begin{array}{l}\text { Low } \\
\text { Educ. }\end{array}$ & $\begin{array}{c}\text { Realit } \\
\mathrm{y}\end{array}$ & $\begin{array}{l}\text { High } \\
\text { Educ. }\end{array}$ & $\begin{array}{l}\text { Low } \\
\text { Educ. }\end{array}$ & $\begin{array}{l}\text { Rea- } \\
\text { lity }\end{array}$ & $\begin{array}{l}\text { High } \\
\text { Educ. }\end{array}$ & $\begin{array}{l}\text { Low } \\
\text { Educ. }\end{array}$ & $\begin{array}{l}\text { Rea- } \\
\text { lity }\end{array}$ & $\begin{array}{l}\text { High } \\
\text { Educ. }\end{array}$ & $\begin{array}{l}\text { Low } \\
\text { Educ. }\end{array}$ & $\begin{array}{c}\text { Rea- } \\
\text { lity }\end{array}$ \\
\hline Onsite & -- & -- & 0 & -- & -- & 0 & 0 & 0 & 0 & 0 & 0 & 0 \\
\hline Church & + & + & -- & 0 & 0 & $\mathbf{0}$ & 0 & 0 & $\mathbf{0}$ & + & + & -- \\
\hline National Chain & -- & -- & $\mathbf{0}$ & -- & -- & + & -- & -- & $\mathbf{0}$ & -- & -- & $\mathbf{0}$ \\
\hline PubliclySupport & -- & -- & $\mathbf{0}$ & 0 & 0 & $\mathbf{0}$ & 0 & 0 & $\mathbf{0}$ & 0 & 0 & $\mathbf{0}$ \\
\hline Publicly Owned & 0 & 0 & + & -- & -- & + & 0 & 0 & $\mathbf{0}$ & 0 & 0 & $\mathbf{0}$ \\
\hline Publicly Regul. & 0 & 0 & + & 0 & 0 & $\mathbf{0}$ & 0 & 0 & $\mathbf{0}$ & 0 & 0 & + \\
\hline$\%$ Kids White & 0 & 0 & $\mathbf{0}$ & + & + & $\mathbf{0}$ & + & + & $\mathbf{0}$ & 0 & 0 & $\mathbf{0}$ \\
\hline$\%$ Subsidized & 0 & 0 & -- & 0 & 0 & $\mathbf{0}$ & + & + & -- & 0 & 0 & $\mathbf{0}$ \\
\hline Coff/Cook -NP & 0 & 0 & $\mathbf{0}$ & -- & -- & $\mathbf{0}$ & + & 0 & $\mathbf{0}$ & -- & -- & + \\
\hline Clean Entry-NP & + & 0 & -- & -- & 0 & $\mathbf{0}$ & + & + & $\mathbf{0}$ & 0 & 0 & -- \\
\hline Dir. Articul.-NP & + & + & + & 0 & + & $\mathbf{0}$ & + & 0 & + & + & 0 & $\mathbf{0}$ \\
\hline Coff/Cook - FP & -- & 0 & $\mathbf{0}$ & -- & -- & + & -- & -- & + & 0 & -- & $\mathbf{0}$ \\
\hline Clean Entry -FP & 0 & 0 & $\mathbf{0}$ & 0 & 0 & + & 0 & 0 & $\mathbf{0}$ & 0 & 0 & $\mathbf{0}$ \\
\hline Dir. Articul.-FP & + & -- & + & 0 & 0 & $\mathbf{0}$ & + & 0 & $\mathbf{0}$ & 0 & 0 & $\mathbf{0}$ \\
\hline
\end{tabular}

\begin{tabular}{|c|c|c|c|c|c|c|c|c|c|c|c|c|}
\hline \multirow[b]{2}{*}{ Variable } & \multicolumn{3}{|c|}{ Music Activities } & \multicolumn{3}{|c|}{ Pretend Play } & \multicolumn{3}{|c|}{ Small Muscle Activities } & \multicolumn{3}{|c|}{ Sand Water } \\
\hline & $\begin{array}{l}\text { High } \\
\text { Educ. }\end{array}$ & $\begin{array}{l}\text { Low } \\
\text { Educ. }\end{array}$ & $\begin{array}{l}\text { Rea- } \\
\text { lity }\end{array}$ & $\begin{array}{l}\text { High } \\
\text { Educ. }\end{array}$ & $\begin{array}{l}\text { Low } \\
\text { Educ. }\end{array}$ & $\begin{array}{l}\text { Rea- } \\
\text { lity }\end{array}$ & $\begin{array}{l}\text { High } \\
\text { Educ. }\end{array}$ & $\begin{array}{l}\text { Low } \\
\text { Educ. }\end{array}$ & $\begin{array}{l}\text { Rea- } \\
\text { lity }\end{array}$ & $\begin{array}{l}\text { High } \\
\text { Educ }\end{array}$ & $\begin{array}{l}\text { Low } \\
\text { Educ. }\end{array}$ & $\begin{array}{l}\text { Rea- } \\
\text { lity }\end{array}$ \\
\hline Onsite & -- & -- & 0 & -- & -- & $\mathbf{0}$ & 0 & 0 & 0 & 0 & 0 & + \\
\hline Church & 0 & 0 & $\mathbf{0}$ & 0 & 0 & -- & 0 & 0 & -- & 0 & 0 & - \\
\hline National Chain & -- & -- & $\mathbf{0}$ & -- & -- & + & -- & -- & + & -- & -- & $\mathbf{0}$ \\
\hline PubliclySupport & 0 & 0 & $\mathbf{0}$ & 0 & 0 & $\mathbf{0}$ & + & + & $\mathbf{0}$ & 0 & 0 & $\mathbf{0}$ \\
\hline Publicly Owned & 0 & 0 & + & 0 & 0 & $\mathbf{0}$ & -- & -- & $\mathbf{0}$ & + & + & + \\
\hline Publicly Regul. & + & + & $\mathbf{0}$ & 0 & 0 & $\mathbf{0}$ & 0 & 0 & + & 0 & 0 & $\mathbf{0}$ \\
\hline \% Kids White & + & + & $\mathbf{0}$ & 0 & 0 & $\mathbf{0}$ & 0 & 0 & $\mathbf{0}$ & 0 & 0 & $\mathbf{0}$ \\
\hline \% Subsidized & 0 & 0 & $\mathbf{0}$ & 0 & 0 & -- & 0 & 0 & -- & 0 & 0 & -- \\
\hline Coff/Cook -NP & 0 & -- & $\mathbf{0}$ & 0 & 0 & + & 0 & 0 & $\mathbf{0}$ & 0 & 0 & $\mathbf{0}$ \\
\hline Clean Entry-NP & -- & 0 & -- & 0 & 0 & -- & + & + & $\mathbf{0}$ & -- & 0 & $\mathbf{0}$ \\
\hline Dir. Articul.-NP & + & 0 & + & + & 0 & $\mathbf{0}$ & 0 & 0 & + & + & 0 & + \\
\hline Coff/Cook - FP & 0 & -- & $\mathbf{0}$ & 0 & -- & $\mathbf{0}$ & 0 & 0 & $\mathbf{0}$ & 0 & 0 & + \\
\hline Clean Entry -FP & 0 & 0 & $\mathbf{0}$ & 0 & 0 & $\mathbf{0}$ & 0 & 0 & + & 0 & 0 & $\mathbf{0}$ \\
\hline Dir. Articul.-FP & 0 & 0 & $\mathbf{0}$ & 0 & + & + & 0 & 0 & $\mathbf{0}$ & 0 & 0 & $\mathbf{0}$ \\
\hline
\end{tabular}

The signs in the cells represent the direction of the relationship between the variable and the parents' perception as well as actual classroom quality. Publicly Support $=$ Publicly Supported, Publicly Regul. $=$ Publicly Regulated, Coff $/$ Cook $=$ Coffee and Cookies, Dir. Articul. = Articulate Director, NP = Non-Profit, FP $=$ For-Profit. 
(Table 7 Concluded)

Comparisons of Individual Questions

\begin{tabular}{|c|c|c|c|c|c|c|c|c|c|c|c|c|}
\hline \multirow[b]{2}{*}{ Variable } & \multicolumn{3}{|c|}{$\begin{array}{c}\text { Furniture for Routine } \\
\text { Care }\end{array}$} & \multicolumn{3}{|c|}{$\begin{array}{c}\text { Furniture for Play and } \\
\text { Learning }\end{array}$} & \multicolumn{3}{|c|}{ Room Arrangement } & \multicolumn{3}{|c|}{ Softness in Room } \\
\hline & $\begin{array}{l}\text { High } \\
\text { Educ. }\end{array}$ & $\begin{array}{l}\text { Low } \\
\text { Educ }\end{array}$ & $\begin{array}{l}\text { Rea- } \\
\text { lity }\end{array}$ & $\begin{array}{l}\text { High } \\
\text { Educ. }\end{array}$ & $\begin{array}{l}\text { Low } \\
\text { Educ. }\end{array}$ & $\begin{array}{l}\text { Rea- } \\
\text { lity }\end{array}$ & $\begin{array}{l}\text { High } \\
\text { Educ. }\end{array}$ & $\begin{array}{l}\text { Low } \\
\text { Educ }\end{array}$ & $\begin{array}{l}\text { Rea- } \\
\text { lity }\end{array}$ & $\begin{array}{l}\text { High } \\
\text { Educ. }\end{array}$ & $\begin{array}{l}\text { Low } \\
\text { Educ. }\end{array}$ & $\begin{array}{l}\text { Rea- } \\
\text { lity }\end{array}$ \\
\hline Onsite & 0 & 0 & $\mathbf{0}$ & 0 & 0 & 0 & 0 & 0 & 0 & -- & -- & $\mathbf{0}$ \\
\hline Church & 0 & 0 & -- & + & + & $\mathbf{0}$ & + & + & -- & -- & -- & -- \\
\hline National Chain & -- & -- & $\mathbf{0}$ & -- & -- & + & -- & -- & + & -- & -- & + \\
\hline PubliclySupport & 0 & 0 & $\mathbf{0}$ & 0 & 0 & $\mathbf{0}$ & 0 & 0 & $\mathbf{0}$ & 0 & 0 & $\mathbf{0}$ \\
\hline Publicly Owned & 0 & 0 & $\mathbf{0}$ & + & + & + & 0 & 0 & $\mathbf{0}$ & 0 & 0 & $\mathbf{0}$ \\
\hline Publicly Regul. & 0 & 0 & $\mathbf{0}$ & 0 & 0 & + & 0 & 0 & + & + & + & $\mathbf{0}$ \\
\hline \% Kids White & -- & -- & + & 0 & 0 & $\mathbf{0}$ & + & + & $\mathbf{0}$ & + & + & $\mathbf{0}$ \\
\hline \% Subsidized & -- & -- & $\mathbf{0}$ & -- & -- & $\mathbf{0}$ & 0 & 0 & $\mathbf{0}$ & 0 & 0 & $\mathbf{0}$ \\
\hline Coff/Cook -NP & + & + & $\mathbf{0}$ & 0 & -- & $\mathbf{0}$ & + & 0 & $\mathbf{0}$ & -- & -- & $\mathbf{0}$ \\
\hline Clean Entry-NP & + & + & + & 0 & 0 & $\mathbf{0}$ & + & 0 & $\mathbf{0}$ & + & 0 & -- \\
\hline Dir. Articul.-NP & -- & -- & + & 0 & 0 & + & 0 & 0 & + & + & 0 & $\mathbf{0}$ \\
\hline Coff/Cook - FP & -- & -- & 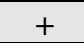 & 0 & 0 & 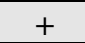 & -- & -- & $\mathbf{0}$ & 0 & 0 & + \\
\hline Clean Entry -FP & + & + & $\mathbf{0}$ & 0 & 0 & + & + & 0 & $\mathbf{0}$ & 0 & 0 & $\mathbf{0}$ \\
\hline Dir. Articul.-FP & + & + & $\overline{\mathbf{0}}$ & 0 & 0 & $\mathbf{0}$ & 0 & 0 & + & 0 & 0 & $\mathbf{0}$ \\
\hline
\end{tabular}

\begin{tabular}{|c|c|c|c|c|c|c|c|c|c|c|c|c|}
\hline \multirow[b]{2}{*}{ Variable } & \multicolumn{3}{|c|}{ Room Decoration } & \multicolumn{3}{|c|}{$\begin{array}{l}\text { Activities for Different } \\
\text { Cultures }\end{array}$} & \multicolumn{3}{|c|}{$\begin{array}{l}\text { Arriving and Leaving } \\
\text { times }\end{array}$} & \multicolumn{3}{|c|}{ Daily Schedule } \\
\hline & $\begin{array}{l}\text { High } \\
\text { Educ. }\end{array}$ & $\begin{array}{l}\text { Low } \\
\text { Educ. }\end{array}$ & $\begin{array}{c}\text { Realit } \\
y\end{array}$ & $\begin{array}{l}\text { High } \\
\text { Educ. }\end{array}$ & $\begin{array}{l}\text { Low } \\
\text { Educ. }\end{array}$ & $\begin{array}{l}\text { Rea- } \\
\text { lity }\end{array}$ & $\begin{array}{l}\text { High } \\
\text { Educ. }\end{array}$ & $\begin{array}{l}\text { Low } \\
\text { Educ. }\end{array}$ & $\begin{array}{l}\text { Rea- } \\
\text { lity }\end{array}$ & $\begin{array}{l}\text { High } \\
\text { Educ. }\end{array}$ & $\begin{array}{l}\text { Low } \\
\text { Educ. }\end{array}$ & $\begin{array}{l}\text { Rea- } \\
\text { lity }\end{array}$ \\
\hline Onsite & 0 & 0 & + & 0 & 0 & 0 & 0 & 0 & 0 & 0 & 0 & + \\
\hline Church & 0 & 0 & -- & 0 & 0 & -- & -- & -- & -- & -- & -- & -- \\
\hline National Chain & -- & -- & + & -- & -- & $\mathbf{0}$ & -- & -- & $\mathbf{0}$ & 0 & 0 & $\mathbf{0}$ \\
\hline PubliclySupport & -- & -- & $\mathbf{0}$ & 0 & 0 & $\mathbf{0}$ & 0 & 0 & $\mathbf{0}$ & 0 & 0 & $\mathbf{0}$ \\
\hline Publicly Owned & -- & -- & $\mathbf{0}$ & 0 & 0 & + & -- & -- & $\mathbf{0}$ & 0 & 0 & + \\
\hline Publicly Regul. & 0 & 0 & + & 0 & 0 & $\mathbf{0}$ & 0 & 0 & $\mathbf{0}$ & -- & -- & + \\
\hline$\%$ Kids White & 0 & 0 & + & 0 & 0 & -- & -- & -- & $\mathbf{0}$ & 0 & 0 & -- \\
\hline \% Subsidized & 0 & 0 & $\mathbf{0}$ & 0 & 0 & $\mathbf{0}$ & 0 & 0 & -- & + & + & -- \\
\hline Coff/Cook -NP & 0 & -- & $\mathbf{0}$ & + & 0 & $\mathbf{0}$ & 0 & -- & $\mathbf{0}$ & 0 & 0 & $\mathbf{0}$ \\
\hline Clean Entry-NP & + & 0 & $\mathbf{0}$ & 0 & 0 & $\mathbf{0}$ & 0 & 0 & $\mathbf{0}$ & 0 & 0 & $\mathbf{0}$ \\
\hline Dir. Articul.-NP & -- & 0 & $\mathbf{0}$ & 0 & 0 & + & + & 0 & $\mathbf{0}$ & 0 & 0 & + \\
\hline Coff/Cook - FP & + & 0 & $\mathbf{0}$ & 0 & 0 & + & -- & -- & $\mathbf{0}$ & 0 & 0 & $\mathbf{0}$ \\
\hline Clean Entry -FP & 0 & 0 & + & 0 & 0 & + & + & 0 & $\mathbf{0}$ & 0 & 0 & + \\
\hline Dir. Articul.-FP & 0 & 0 & + & 0 & 0 & $\mathbf{0}$ & 0 & + & + & 0 & 0 & + \\
\hline
\end{tabular}

The signs in the cells represent the direction of the relationship between the variable and the parents' perception as well as actual classroom quality. Publicly Support $=$ Publicly Supported, Publicly Regul.$=$ Publicly Regulated, Coff $/$ Cook $=$ Coffee and Cookies, Dir. Articul. $=$ Articulate Director, NP $=$ Non-Profit, $\mathrm{FP}=$ For-Profit . 


\section{$\underline{X . \quad \text { References }}$}

Akerlof, George A., 1970, “The Market for 'Lemons': Quality Uncertainty and the Market Mechanism," Quarterly Journal of Economics, 84(3): 488-500.

Beckman, Steven R., 1992, "The Sources of Forecast Errors: Experimental Evidence" Journal of Economic Behavior and Organization, 19: 237-244.

Bergmann, Barbara R., 1996. Saving Our Children from Poverty: What the United States Can Learn from France. New York: Russell Sage Foundation.

Blau, David M., 1997. "The Production of Quality in Child Care Centers," Journal of Human Resources 32(2): 354-87.

Bond, Eric W. Source, 1982, "A Direct Test of the "Lemons" Model: The Market for Used Pickup Trucks", American Economic Review, September, Vol. 72, No. 4: 836-40.

Buzzell, Robert D., Robert E. M. Nourse, John B. Mathews, and Theodore Levitt, 1972. Marketing: A Contemporary Analysis. New York:McGraw-Hill.

Chezum, Brian and Brad Wimmer 1997. "Roses or Lemons: Adverse Selection in the Market for Thoroughbred Yearlings," The Review of Economics and Statistics, LXXIX, pp. 521-6.

Cooper, Russell, and Thomas W. Ross, 1984, "Prices, Product Qualities and Asymmetric Information: The Competitive Case," The Review of Economic Studies, 51:2, pp. 197-207.

Cryer, Debby and Margaret Burchinal, 1997, "Parents as Child Care Consumers," Early Childhood Research Quarterly, 12:1, pp. 35-58.

Feenberg, Daniel R., William Gentry, David Gilroy and Harvey S. Rosen, 1989, "Testing The Rationality of State Revenue Forecasts." Review of Economics and Statistics, 42:429-40.

Genesove, David 1993. "Adverse Selection in the Wholesale Used Car Market," The Journal of Political Economy, 101:4, pp. 644-65.

Gerstner, Eitan, 1985. "Do Higher Prices Signal Higher Quality?" Journal of Marketing Research, 22(May): 209-215.

Greenwald, Bruce C. and Glasspiegel, Robert R. 1983, "Adverse Selection in the Market for Slaves: New Orleans, 1830-1860", Quarterly Journal of Economics, August, Vol. 98, No. 3: 479-99.

Harms, Thelma and Clifford, Richard, 1980. Early Childhood Environment Rating Scale. New York: Teachers College Press.

Harms, Thelma, Deborah Cryer and Richard Clifford, 1990. Infant/Toddler Environment Rating Scale. New York: Teachers College Press.

Hayes, Cheryl D., John L. Palmer and Martha L. Zaslow, eds. 1990, Who Cares For America's Children? Child Care Policy for the 1990s. Washington: National Academy Press.

Heinkel, Robert, 1981, "Uncertain Product Quality: The Market for Lemons with an Imperfect Testing Technology," The Bell Journal of Economics, Autumn, Vol. 12, No. 2: 625-636. 
Hubbard, Thomas N. 1998, "An Empirical Examination of Moral Hazard in the Vehicle Inspection Market," RAND Jourmal of Economics, Vol. 29, No:2, pp. 406-26.

Keane, Michael P. and David E. Runkle 1998. "Are Financial Analysts' Forecasts of Corporate Profits Rational," Journal of Political Economy, 106:4, pp. 768-805.

Lamb, Michael E. 1998. "Nonparental Child Care: Context, Quality, Correlates, and Consequences." In. Child Psychology in Practice, I. Sigel and K. Renninger, eds. Handbook of Child Psychology (Fifth ed.), W. Damon, series ed. New York: Wiley.

Leland, Hayne E., 1979. "Quacks, Lemons and Licensing: A Theory of Minimum Quality Standards," The Journal of Political Economy, December, Vol. 87, No. 6: $1328-1346$.

Love, John M., Peter Z. Schochet, and Alicia L. Meckstroth. 1996. "Are They in Any Real Danger? What Research Does - And Doesn't - Tell Us About Child Care Quality and Children's Well-Being." manuscript, Princeton NJ: Mathematica Policy Research, Inc.

Milgrom, Paul, and John Roberts, 1986. "Price and Advertising Signals of Product Quality," Journal of Political Economy, 94(4): 796-821.

Mocan, Naci H., 1995, "Quality Adjusted Cost Functions for Child Care Centers," The American Economic Review, 85(2): 409-413.

Mocan, H. Naci, 1997. "Cost Function, Efficiency, and Quality in Day Care Centers," Journal of Human Resources 32(4): 861-91.

Mocan, Naci H. and Sam Azad, 1995, "Accuracy and Rationality of State General Fund Revenue Forecasts: Evidence from Panel Data," International Journal of Forecasting, 11: 417-427.

Mocan, H. Naci, Margaret Burchinal, John R. Morris, and Suzanne W. Helburn. "Models of Quality in center Child Care," in Suzanne W. Helburn (Ed.) "Cost, Quality, and Child Outcomes in Child Care Centers, Technical Report," Denver, Department of Economics, Center for Research in Economic and Social Policy, University of Colorado at Denver, 1995.

Mocan, H. Naci 2000 "Information Asymmetry in the Market for Child Care." Final Report, Smith Richardson Foundation.

Monroe, Kent B., 1973. "Buyers' Subjective Perceptions of Price," in Harold H. Kassarjian and Thomas S. Robertson, eds., Perspectives in Consumer Behavior, pp. 23-42. Glenview, IL: Scott Foresman.

Mullineaux, Donald, J., 1978, “On testing for Rationality: Another Look at the Livingston Price Expectations Data.” Journal of Political Economy, 86: 329336.

Poterba, James, 1995, Government Intervention in Markets for Education and Health: How and Why, in Fuchs, ed., Individual and Social Responsibility, Chicago, University of Chicago Press: 277-304.

Rosenman Robert E. and Wesley W. Wilson, 1991, "Quality Differentials and Prices: Are Cherries Lemons?" Journal of Industrial Economics, XXXIX:6, pp. 64958. 
Shapiro, C., 1982. "Consumer Information, Product Quality and Seller Reputation," Bell Journal of Economics, 13: 20-35.

Shapiro, C., 1986. "Investment, Moral Hazard, and Occupational Licensing," The Review of Economic Studies, October, Vol. 53, No. 5: 843-862.

Von Ungern-Sternberg, Thomas and von Weizsacker, Christian Carl, 1985, "The Supply of Quality on a Market for "Experienced Goods"”, Journal of Industrial Economics, June, Vol. 33, Issue 4: 531-540.

Weisbrod, Burton A, 1988. The Nonprofit Economy. Cambridge, Mass: Harvard University Press.

Whitebook, Marcy; Howes, Carollee and Phillips, Deborah., 1990, "Who Cares? Child Care Teachers and the Quality of Care in America." Final Report of the National Child Care Staffing Study. Oakland, CA: Child Care Employee Project.

Wolinsky, Asher, 1983. "Prices as Signals of Product Quality," The Review of Economic Studies, 50(4): 647-658. 
Table App-1

Parents' Quality Assessment

\begin{tabular}{|c|c|c|c|}
\hline Variables & Description & $\begin{array}{l}\text { Parent } \\
\text { Rating }\end{array}$ & $\begin{array}{l}\text { Actual } \\
\text { Rating }\end{array}$ \\
\hline $\begin{array}{l}\text { Furniture for } \\
\text { Routine Care }\end{array}$ & $\begin{array}{l}\text { Comfortable; Safe; Enough for all children; Always individual } \\
\text { care; Child-sized to encourage independence; Easy for adults to } \\
\text { use. }\end{array}$ & $\begin{array}{l}5.129 \\
(1.693) \\
\mathrm{n}=3300\end{array}$ & $\begin{array}{c}6.192 \\
(1.129) \\
n=3108\end{array}$ \\
\hline $\begin{array}{l}\text { Furniture for Play } \\
\text { and Learning }\end{array}$ & $\begin{array}{l}\text { Enough furniture and toys for all children; In good repair and } \\
\text { sturdy. Child-sized so child can be independent; Toys } \\
\text { organized so child can use easily; Extra toys available for more } \\
\text { learning; }\end{array}$ & $\begin{array}{l}4.499 \\
(1.801) \\
\mathrm{n}=3300\end{array}$ & $\begin{array}{c}6.342 \\
(1.093) \\
\mathrm{n}=3105\end{array}$ \\
\hline Softness in Room & $\begin{array}{l}\text { Many easy-to-clean soft toys to cuddle; Quiet cozy area for } \\
\text { quiet play; Rugs or carpet for softness. }\end{array}$ & $\begin{array}{c}3.843 \\
(1.600) \\
\mathrm{n}=3300\end{array}$ & $\begin{array}{c}5.438 \\
(1.676) \\
\mathrm{n}=3085 \\
\end{array}$ \\
\hline $\begin{array}{l}\text { Room } \\
\text { Arrangement }\end{array}$ & $\begin{array}{l}\text { Room set up for safe care; Easy supervision of all children; } \\
\text { Enough space, children are not crowded; Allows proper } \\
\text { diapering, feeding and nap; Well-arranged for playing and } \\
\text { learning; Toys well-organized; }\end{array}$ & $\begin{array}{c}4.403 \\
(1.725) \\
\mathrm{n}=3300\end{array}$ & $\begin{array}{c}5.948 \\
(1.399) \\
\mathrm{n}=3100\end{array}$ \\
\hline Room Decoration & $\begin{array}{l}\text { Many colorful photos and pictures; Nothing Scary; Pictures put } \\
\text { where children can see and touch; Helps children learn; } \\
\text { Teacher talks with child about pictures; Toddler's artwork and } \\
\text { photos of children hung up; Pictures changed often; }\end{array}$ & $\begin{array}{l}3.941 \\
(1.282) \\
\mathrm{n}=3294\end{array}$ & $\begin{array}{c}5.907 \\
(1.689) \\
\mathrm{n}=3118\end{array}$ \\
\hline $\begin{array}{l}\text { Arriving and } \\
\text { Leaving Times }\end{array}$ & $\begin{array}{l}\text { Parents and child welcomed into classroom; Child's } \\
\text { unhappiness handled kindly; Pleasant, organized pick-up time; } \\
\text { Parents and teacher share information; Parents invited into } \\
\text { child care area to see what goes on;. }\end{array}$ & $\begin{array}{l}4.347 \\
(1.599) \\
\mathrm{n}=3291\end{array}$ & $\begin{array}{l}6.015 \\
(1.281) \\
\mathrm{n}=3111\end{array}$ \\
\hline Meals and Snacks & $\begin{array}{l}\text { Healthful; Fixed and served in sanitary way; Child fed when } \\
\text { hungry; No bottles in bed to avoid health problems; Child not } \\
\text { forced to eat; Cooperates with parents about food; Pleasant } \\
\text { learning time; Infants held while fed (no propped bottles); } \\
\text { Child learns to do things for self as ready; Adult talks with } \\
\text { child during meals; }\end{array}$ & $\begin{array}{l}3.765 \\
(1.788) \\
\mathrm{n}=3298\end{array}$ & $\begin{array}{c}5.107 \\
(2.561) \\
\mathrm{n}=3118\end{array}$ \\
\hline Nap Time & $\begin{array}{l}\text { Well-supervised; Length and time of nap good for each child; } \\
\text { Sanitary to avoid spread of germs; Children helped to go to } \\
\text { sleep; When awake, children are taken out of crib or allowed to } \\
\text { get up and play. }\end{array}$ & $\begin{array}{l}4.448 \\
(1.847) \\
\mathrm{n}=3268\end{array}$ & $\begin{array}{c}5.221 \\
(2.499) \\
\mathrm{n}=3082\end{array}$ \\
\hline $\begin{array}{l}\text { Diapering and } \\
\text { Toileting }\end{array}$ & $\begin{array}{l}\text { Sanitary to avoid spread of illness; Diapers changed as needed; } \\
\text { Parents informed about daily diapering/toileting; Pleasant time } \\
\text { to talk with child; Self-help skills taught when child ready; } \\
\text { Cooperates with parents in toilet training. }\end{array}$ & $\begin{array}{c}4.02 \\
(2.207) \\
\mathrm{n}=3299\end{array}$ & $\begin{array}{c}5.383 \\
(2.308) \\
\mathrm{n}=3065\end{array}$ \\
\hline $\begin{array}{l}\text { Keeping Children } \\
\text { Clean and Neat }\end{array}$ & $\begin{array}{l}\text { Child's face and hands kept clean; Individual comb, towel, etc. } \\
\text { used; Dirty clothes changed when needed. }\end{array}$ & $\begin{array}{c}3.72 \\
(1.384) \\
n=3288\end{array}$ & $\begin{array}{c}5.687 \\
(1.614) \\
\mathrm{n}=3100\end{array}$ \\
\hline
\end{tabular}




\begin{tabular}{|c|c|c|c|}
\hline $\begin{array}{l}\text { Talking with } \\
\text { Children }\end{array}$ & $\begin{array}{l}\text { Lots of talking to each child; Teacher answers child's crying } \\
\text { sounds, words, and questions; Child helped to learn to talk. }\end{array}$ & $\begin{array}{l}4.424 \\
(1.689) \\
n=3300\end{array}$ & $\begin{array}{c}5.481 \\
(2.199) \\
n=3070\end{array}$ \\
\hline $\begin{array}{l}\text { Small Mus } \\
\text { Activities }\end{array}$ & $\begin{array}{l}\text { Lots of small muscle toys-rattles, busy boxes, etc. for infants, } \\
\text { sorting games, big beads, easy puzzles, etc. for toddlers; Toys } \\
\text { used everyday; teacher helps children develop skills; }\end{array}$ & $\begin{array}{l}5.006 \\
(1.530) \\
n=3300\end{array}$ & $\begin{array}{l}5.887 \\
(1.895) \\
\mathrm{n}=3088\end{array}$ \\
\hline $\begin{array}{l}\text { Art Activities for } \\
\text { Children }\end{array}$ & $\begin{array}{l}\text { Toddlers often use crayons, watercolor markers, paints, play } \\
\text { dough; Teacher supervises with interest; Children take part in } \\
\text { art if interested; not forced to; Child's own creativity } \\
\text { encouraged; }\end{array}$ & $\begin{array}{l}3.734 \\
(1.847) \\
\mathrm{n}=3214\end{array}$ & $\begin{array}{l}5.256 \\
(2.468) \\
n=3086\end{array}$ \\
\hline Music Activities & $\begin{array}{l}\text { Music everyday; Teacher often sings with children; Children } \\
\text { use many music toys; Children dance, clap, sing along; } \\
\text { Different types of music used; }\end{array}$ & $\begin{array}{l}4.682 \\
(1.583) \\
n=3296\end{array}$ & $\begin{array}{c}5.083 \\
(2.414) \\
\mathrm{n}=3091\end{array}$ \\
\hline $\begin{array}{l}\text { Activities with } \\
\text { Blocks }\end{array}$ & $\begin{array}{l}\text { Toddlers can use variety of blocks; many toys to use with } \\
\text { blocks-containers to fill and dump, toy trucks, animals, etc.; } \\
\text { teacher plays with child; Children can use blocks daily. }\end{array}$ & $\begin{array}{c}4.092 \\
(1.935) \\
n=3272\end{array}$ & $\begin{array}{c}4.11 \\
(2.874) \\
n=3101\end{array}$ \\
\hline Pretend Play & $\begin{array}{l}\text { Many pretend play toys-soft dolls and animals, mirror, etc. for } \\
\text { infants; dress up clothes, toy dishes, dolls, toy telephones, etc. } \\
\text { for toddlers; Children use toys everyday; Toys used indoors } \\
\text { and outdoors; Teacher pretends with children in play. }\end{array}$ & $\begin{array}{c}3.44 \\
(1.471) \\
\mathrm{n}=3293\end{array}$ & $\begin{array}{l}5.305 \\
(2.310) \\
n=3048\end{array}$ \\
\hline $\begin{array}{l}\text { Sand and Water } \\
\text { Play }\end{array}$ & $\begin{array}{l}\text { Sand and water play for toddlers, Plenty of toys for sand/water } \\
\text { play; Closely supervised by teacher; Adult talks with children } \\
\text { about their sand/water play; }\end{array}$ & $\begin{array}{l}4.245 \\
(1.864) \\
n=3204\end{array}$ & $\begin{array}{l}4.327 \\
(2.691) \\
\mathrm{n}=3037\end{array}$ \\
\hline $\begin{array}{l}\text { Activities for } \\
\text { Different } \\
\text { Cultures }\end{array}$ & $\begin{array}{l}\text { Dolls, books and pictures show people of different race, age, } \\
\text { and culture; Pictures show men and women, boys and girls all } \\
\text { doing same work and play; Cultural variety in music, holidays, } \\
\text { foods; }\end{array}$ & $\begin{array}{l}2.725 \\
(1.580) \\
n=3300\end{array}$ & $\begin{array}{l}4.232 \\
(2.813) \\
n=3060\end{array}$ \\
\hline Daily Schedule & $\begin{array}{l}\text { Plenty of time for care and play; Flexible schedule meets each } \\
\text { child's needs; Children do not have to wait long for attention or } \\
\text { for something to do; Parents can see written schedule; }\end{array}$ & $\begin{array}{c}4.757 \\
(1.559) \\
\mathrm{n}=3299\end{array}$ & $\begin{array}{c}6.348 \\
(1.313) \\
n=3065\end{array}$ \\
\hline $\begin{array}{l}\text { Total Quality } \\
\text { Score }\end{array}$ & Average score of the items listed above. & $\begin{array}{c}4.288 \\
(1.088) \\
n=3300\end{array}$ & $\begin{array}{l}5.459 \\
(1.176) \\
\mathrm{n}=3133\end{array}$ \\
\hline $\begin{array}{l}\text { Observable } \\
\text { Quality Score }\end{array}$ & $\begin{array}{l}\text { Average score of the easy-to-observe items (see the text for } \\
\text { specific items included). }\end{array}$ & $\begin{array}{c}4.294 \\
(1.080) \\
n=3300\end{array}$ & $\begin{array}{c}5.585 \\
(1.054) \\
n=3133\end{array}$ \\
\hline $\begin{array}{l}\text { Unobservable } \\
\text { Quality Score }\end{array}$ & $\begin{array}{l}\text { Average score of the difficult-to-observe items (see the text for } \\
\text { specific items included). }\end{array}$ & $\begin{array}{c}4.275 \\
(1.151) \\
n=3300\end{array}$ & $\begin{array}{c}5.333 \\
(1.380) \\
n=3133\end{array}$ \\
\hline $\begin{array}{l}\text { Observable } \\
\text { Quality Score-1 }\end{array}$ & $\begin{array}{l}\text { Average score of the easy-to-observe items; alternative } \\
\text { definition (see the text for specific items included). }\end{array}$ & $\begin{array}{c}4.489 \\
(1.067) \\
n=3300\end{array}$ & $\begin{array}{c}5.948 \\
(0.944) \\
n=3133\end{array}$ \\
\hline $\begin{array}{l}\text { Unobservable } \\
\text { Quality Score-1 }\end{array}$ & $\begin{array}{l}\text { Average score of the difficult-to-observe items; alternative } \\
\text { definition (see the text for specific items included). }\end{array}$ & $\begin{array}{c}4.098 \\
(1.162) \\
n=3300\end{array}$ & $\begin{array}{c}4.99 \\
(1.555) \\
n=3133\end{array}$ \\
\hline
\end{tabular}

The values in the cells are the means. The standard deviations are in parentheses. 
Table App-2

Weak Rationality

\begin{tabular}{|c|c|c|c|c|c|c|c|}
\hline \multirow[b]{2}{*}{ Variables } & \multirow[b]{2}{*}{ Slope } & \multirow[b]{2}{*}{ Std. Err. } & \multirow[b]{2}{*}{$R^{2}$} & \multicolumn{2}{|c|}{$\mathbf{H}_{0}: \beta_{I}=1$} & \multicolumn{2}{|c|}{$\mathbf{H}_{0}: \beta_{0}=0, \beta_{I}=1$} \\
\hline & & & & $F$ - value & $p$ - value & $F$ - value & $p$ - value \\
\hline Furniture for Routine Care & $0.029 * *$ & $(0.013)$ & 0.013 & 5822.98 & 0.000 & 3400.13 & 0.000 \\
\hline Furniture for Play and Learning & $0.025^{* *}$ & $(0.011)$ & 0.081 & 7781.07 & 0.000 & 5980.78 & 0.000 \\
\hline Softness in Room & $0.166 * * *$ & $(0.019)$ & 0.035 & 1994.75 & 0.000 & 1234.36 & 0.000 \\
\hline Room Arrangement & $0.079 * * *$ & $(0.016)$ & 0.017 & 3449.05 & 0.000 & 2331.85 & 0.000 \\
\hline Room Decoration & $0.103 * * *$ & $(0.022)$ & 0.126 & 1614.40 & 0.000 & 1488.53 & 0.000 \\
\hline Arriving and Leaving Times & $0.074 * * *$ & $(0.014)$ & 0.031 & 4097.91 & 0.000 & 2664.91 & 0.000 \\
\hline Meals and Snacks & $0.118 * * *$ & $(0.028)$ & 0.020 & 1027.17 & 0.000 & 640.23 & 0.000 \\
\hline Nap Time & $0.073 * * *$ & $(0.025)$ & 0.016 & 1342.84 & 0.000 & 724.39 & 0.000 \\
\hline Diapering and Toileting & 0.027 & $(0.023)$ & 0.031 & 1845.20 & 0.000 & 1395.02 & 0.000 \\
\hline Keeping Children Clean and Neat & $0.100 * * *$ & $(0.022)$ & 0.026 & 1635.39 & 0.000 & 1263.52 & 0.000 \\
\hline Talking with Children & $0.176 * * *$ & $(0.023)$ & 0.053 & 1232.29 & 0.000 & 719.58 & 0.000 \\
\hline Small Muscle Activities & $0.140 * * *$ & $(0.023)$ & 0.025 & 1348.69 & 0.000 & 714.36 & 0.000 \\
\hline Art Activities for Children & $0.197 * * *$ & $(0.024)$ & 0.041 & 1110.76 & 0.000 & 725.11 & 0.000 \\
\hline Music Activities & $0.171 * * *$ & $(0.032)$ & 0.025 & 660.04 & 0.000 & 334.08 & 0.000 \\
\hline Activities with Blocks & $0.164 * * *$ & $(0.027)$ & 0.058 & 925.62 & 0.000 & 477.76 & 0.000 \\
\hline Pretend Play & $0.259 * * *$ & $(0.028)$ & 0.068 & 688.11 & 0.000 & 534.19 & 0.000 \\
\hline Sand and Water Play & $0.269 * * *$ & $(0.028)$ & 0.061 & 660.14 & 0.000 & 330.08 & 0.000 \\
\hline Activities for Different Cultures & $0.296 * * *$ & $(0.032)$ & 0.093 & 495.48 & 0.000 & 313.16 & 0.000 \\
\hline Daily Schedule & $0.040 * *$ & $(0.017)$ & 0.027 & 3316.35 & 0.000 & 2175.63 & 0.000 \\
\hline Total Quality Score & $0.226 * * *$ & $(0.021)$ & 0.067 & 1423.05 & 0.000 & 1147.20 & 0.000 \\
\hline $\begin{array}{l}\text { Total Quality Score for Observable } \\
\text { Characteristics }\end{array}$ & $0.190 * * *$ & $(0.019)$ & 0.069 & 1882.94 & 0.000 & 1580.91 & 0.000 \\
\hline $\begin{array}{l}\text { Total Quality Score for } \\
\text { Unobservable Characteristics }\end{array}$ & $0.238 * * *$ & $(0.022)$ & 0.062 & 1148.02 & 0.000 & 838.69 & 0.000 \\
\hline Observable Quality Score-1 & $0.154 * * *$ & $(0.017)$ & 0.048 & 2617.84 & 0.000 & 2460.12 & 0.000 \\
\hline Unobservable Quality Score-1 & $0.284 * * *$ & $(0.026)$ & 0.067 & 762.29 & 0.000 & 499.29 & 0.000 \\
\hline
\end{tabular}

* indicates statistical significance between $10 \%$ and $5 \%$;* indicates statistical significance between $5 \%$

(inclusive) and $1 \%$; ** indicates statistical significance at the $1 \%$ level or better. 
Table App-3

Weak Rationality Reverse Regression

\begin{tabular}{|c|c|c|c|c|c|c|c|}
\hline \multirow[b]{2}{*}{ Variables } & \multirow[b]{2}{*}{ Slope } & \multirow[b]{2}{*}{ Std. Err. } & \multirow{2}{*}{$R^{2}$} & \multicolumn{2}{|c|}{$\mathbf{H}_{0}: \beta_{I}=1$} & \multicolumn{2}{|c|}{$\mathbf{H}_{0}: \beta_{0}=\mathbf{0}, \beta_{I}=\mathbf{1}$} \\
\hline & & & & $F$ - value & $p$ - value & $F$ - value & $p$ - value \\
\hline Furniture for Routine Care & $0.058^{* * *}$ & $(0.025)$ & 0.112 & 1385.16 & 0.000 & 938.25 & 0.000 \\
\hline Furniture for Play and Learning & $0.065 * *$ & $(0.029)$ & 0.103 & 1028.62 & 0.000 & 1307.29 & 0.000 \\
\hline Softness in Room & $0.151 * * *$ & $(0.017)$ & 0.034 & 2507.63 & 0.000 & 1514.75 & 0.000 \\
\hline Room Arrangement & $0.103 * * *$ & $(0.020)$ & 0.155 & 1925.90 & 0.000 & 1428.89 & 0.000 \\
\hline Room Decoration & $0.066 * * *$ & $(0.014)$ & 0.028 & 4251.49 & 0.000 & 3187.70 & 0.000 \\
\hline Arriving and Leaving Times & $0.114 * * *$ & $(0.022)$ & 0.050 & 1599.47 & 0.000 & 1201.77 & 0.000 \\
\hline Meals and Snacks & $0.050 * * *$ & $(0.012)$ & 0.143 & 6700.64 & 0.000 & 3650.54 & 0.000 \\
\hline Nap Time & $0.037 * * *$ & $(0.013)$ & 0.074 & 5544.62 & 0.000 & 2875.94 & 0.000 \\
\hline Diapering and Toileting & 0.018 & $(0.014)$ & 0.330 & 4634.03 & 0.000 & 3058.08 & 0.000 \\
\hline Keeping Children Clean and Neat & $0.065^{* * *}$ & $(0.014)$ & 0.142 & 4179.56 & 0.000 & 2775.84 & 0.000 \\
\hline Talking with Children & $0.102 * * *$ & $(0.014)$ & 0.073 & 4327.17 & 0.000 & 2341.54 & 0.000 \\
\hline Small Muscle Activities & $0.082 * * *$ & $(0.014)$ & 0.108 & 4499.45 & 0.000 & 2318.19 & 0.000 \\
\hline Art Activities for Children & $0.110 * * *$ & $(0.013)$ & 0.084 & 4344.40 & 0.000 & 2475.20 & 0.000 \\
\hline Music Activities & $0.053 * * *$ & $(0.010)$ & 0.286 & 9035.56 & 0.000 & 4530.93 & 0.000 \\
\hline Activities with Blocks & $0.070 * * *$ & $(0.012)$ & 0.107 & 6291.75 & 0.000 & 3180.93 & 0.000 \\
\hline Pretend Play & $0.104 * * *$ & $(0.011)$ & 0.067 & 6231.39 & 0.000 & 3588.85 & 0.000 \\
\hline Sand and Water Play & $0.109 * * *$ & $(0.012)$ & 0.210 & 5941.98 & 0.000 & 2971.00 & 0.000 \\
\hline Activities for Different Cultures & $0.094 * * *$ & $(0.010)$ & 0.094 & 8093.09 & 0.000 & 4251.99 & 0.000 \\
\hline Daily Schedule & $0.047 * *$ & $(0.020)$ & 0.186 & 2374.43 & 0.000 & 1628.22 & 0.000 \\
\hline Total Quality Score & $0.166 * * *$ & $(0.015)$ & 0.192 & 3091.30 & 0.000 & 2141.07 & 0.000 \\
\hline $\begin{array}{l}\text { Total Quality Score for Observable } \\
\text { Characteristics }\end{array}$ & $0.169 * * *$ & $(0.017)$ & 0.201 & 2510.01 & 0.000 & 1974.48 & 0.000 \\
\hline $\begin{array}{l}\text { Total Quality Score for } \\
\text { Unobservable Characteristics }\end{array}$ & $0.145 * * *$ & $(0.014)$ & 0.169 & 3878.31 & 0.000 & 2372.88 & 0.000 \\
\hline Observable Quality Score-1 & $0.175 * * *$ & $(0.019)$ & 0.141 & 1921.36 & 0.000 & 1972.31 & 0.000 \\
\hline Unobservable Quality Score-1 & $0.130 * * *$ & $(0.012)$ & 0.226 & 5359.84 & 0.000 & 2937.72 & 0.000 \\
\hline
\end{tabular}

$*$ indicates statistical significance between $10 \%$ and $5 \%$; ** indicates statistical significance between $5 \%$ (inclusive) and $1 \%$; ** indicates statistical significance at the $1 \%$ level or better. 
Table App-4

Weak Rationality, Reverse Regression, IV Estimates

\begin{tabular}{|c|c|c|c|c|c|c|}
\hline \multirow[b]{2}{*}{ Variables } & \multirow[b]{2}{*}{ Slope } & \multirow[b]{2}{*}{ Std. Err. } & \multicolumn{2}{|c|}{ Ho: $\beta_{1}=1$} & \multicolumn{2}{|c|}{ Ho: $\beta_{0}=0, \beta_{1}=1$} \\
\hline & & & $F$-value & $p$-value & $F$-value & $p$-value \\
\hline Furniture for Routine Care & 0.161 & $(0.250)$ & 11.26 & 0.001 & 121.59 & 0.000 \\
\hline Furniture for Play and Learning & $1.563 * * *$ & $(0.323)$ & 3.05 & 0.081 & 322.04 & 0.000 \\
\hline Softness in Room & $0.946 * * *$ & $(0.129)$ & 0.18 & 0.675 & 145.91 & 0.000 \\
\hline Room Arrangement & $1.414 * * *$ & $(0.203)$ & 4.15 & 0.042 & 158.08 & 0.000 \\
\hline Room Decoration & $0.953 * * *$ & $(0.174)$ & 0.07 & 0.787 & 441.54 & 0.000 \\
\hline Arriving and Leaving Times & $0.957 * * *$ & $(0.158)$ & 0.07 & 0.788 & 172.13 & 0.000 \\
\hline Meals and Snacks & $0.828 * * *$ & $(0.110)$ & 2.45 & 0.117 & 82.82 & 0.000 \\
\hline Nap Time & 0.144 & $(0.093)$ & 84.32 & 0.000 & 105.77 & 0.000 \\
\hline Diapering and Toileting & $0.669 * * *$ & $(0.183)$ & 3.27 & 0.071 & 358.46 & 0.000 \\
\hline Keeping Children Clean and Neat & 0.181 & $(0.116)$ & 50.03 & 0.000 & 568.14 & 0.000 \\
\hline Talking with Children & $1.252 * * *$ & $(0.146)$ & 2.98 & 0.084 & 42.46 & 0.000 \\
\hline Small Muscle Activities & $1.254 * * *$ & $(0.156)$ & 2.63 & 0.105 & 11.96 & 0.000 \\
\hline Art Activities for Children & $1.32 * * *$ & $(0.190)$ & 2.82 & 0.093 & 62.67 & 0.000 \\
\hline Music Activities & $0.600 * * *$ & $(0.081)$ & 24.18 & 0.000 & 14.55 & 0.000 \\
\hline Activities with Blocks & $1.133 * * *$ & $(0.146)$ & 0.83 & 0.364 & 9.96 & 0.000 \\
\hline Pretend Play & $0.691 * * *$ & $(0.084)$ & 13.55 & 0.000 & 248.64 & 0.000 \\
\hline Sand and Water Play & $1.039 * * *$ & $(0.132)$ & 0.09 & 0.770 & 0.05 & 0.947 \\
\hline Activities for Different Cultures & $0.708 * * *$ & $(0.072)$ & 16.20 & 0.000 & 89.68 & 0.000 \\
\hline Daily Schedule & $1.469 * * *$ & $(0.240)$ & 3.84 & 0.050 & 122.76 & 0.000 \\
\hline Total Quality Score & $1.246 * * *$ & $(0.123)$ & 4.01 & 0.045 & 165.79 & 0.000 \\
\hline $\begin{array}{l}\text { Total Quality Score for Observable } \\
\text { Characteristics } \\
\text { Total Quality Score for Unobservable }\end{array}$ & $1.329 * * *$ & $(0.133)$ & 6.07 & 0.014 & 202.71 & 0.000 \\
\hline Characteristics & $1.15^{* * *}$ & $(0.118)$ & 1.62 & 0.203 & 117.55 & 0.000 \\
\hline Observable Quality Score-1 & $1.423 * * *$ & $(0.157)$ & 7.26 & 0.007 & 304.02 & 0.000 \\
\hline Unobservable Quality Score-1 & $1.069 * * *$ & $(0.105)$ & 0.43 & 0.511 & 59.78 & 0.000 \\
\hline
\end{tabular}

* indicates statistical significance between $10 \%$ and $5 \%$; ** indicates statistical significance between $5 \%$ (inclusive) and 1\%; *** indicates statistical significance at the $1 \%$ level or better. 
Table App-5

Strong Rationality

\begin{tabular}{lcccc}
\hline & Without Quality & \multicolumn{2}{c}{ With Quality } \\
\cline { 2 - 5 } Variables & $\boldsymbol{F}$-value & $\boldsymbol{p}$-value & $\boldsymbol{F}$-value & $\boldsymbol{p}$-value \\
\hline Furniture for Routine Care & 9.13 & 0.000 & 19.34 & 0.000 \\
Furniture for Play and Learning & 17.87 & 0.000 & 17.37 & 0.000 \\
Softness in Room & 6.84 & 0.000 & 5.73 & 0.000 \\
Room Arrangement & 10.13 & 0.000 & 10.52 & 0.000 \\
Room Decoration & 6.11 & 0.000 & 6.91 & 0.000 \\
Arriving and Leaving Times & 10.13 & 0.000 & 10.24 & 0.000 \\
Meals and Snacks & 5.14 & 0.000 & 5.89 & 0.000 \\
Nap Time & 4.93 & 0.000 & 2.54 & 0.000 \\
Diapering and Toileting & 10.90 & 0.000 & 3.72 & 0.000 \\
Keeping Children Clean and Neat & 4.95 & 0.000 & 9.54 & 0.000 \\
Talking with Children & 2.98 & 0.000 & 4.45 & 0.000 \\
Small Muscle Activities & 2.87 & 0.000 & 5.37 & 0.000 \\
Art Activities for Children & 4.57 & 0.000 & 3.68 & 0.000 \\
Music Activities & 3.16 & 0.000 & 5.39 & 0.000 \\
Activities with Blocks & 3.42 & 0.000 & 3.97 & 0.000 \\
Pretend Play & 3.51 & 0.000 & 4.84 & 0.000 \\
Sand and Water Play & 2.61 & 0.000 & 3.44 & 0.000 \\
Activities for Different Cultures & 4.94 & 0.000 & 5.71 & 0.000 \\
Daily Schedule & 11.38 & 0.000 & 10.46 & 0.000 \\
Total Quality Score & 6.27 & 0.000 & 9.60 & 0.000 \\
Total Quality Score for Observable Characteristics & 7.37 & 0.000 & 11.34 & 0.000 \\
Total Quality Score for Unobservable Characteristics & 5.46 & 0.000 & 7.99 & 0.000 \\
Observable Quality Score-1 & 10.23 & 0.000 & 15.54 & 0.000 \\
Unobservable Quality Score-1 & 3.76 & 0.000 & 6.10 & 0.000 \\
\hline
\end{tabular}

